\title{
THE EMERGING RIGHT OF WEST BANK PALESTINIANS TO ISRAELI CITIZENSHIP
}

\author{
ARIEL ZEMACH*
}

\begin{abstract}
This Article explores a path in international law for recognizing the right of the Palestinian population of the West Bank to Israeli citizenship, based on the annexationist policies of Israel in the West Bank. The scope of the obligation of states to confer citizenship on individuals is determined by international human rights law ("IHRL"). The Article shows that a plausible reading of the IHRL treaty obligations of Israel suggests that it has a duty to grant citizenship to individuals born in its territory, who would otherwise be stateless, and that most West Bank Palestinians are currently considered stateless. Therefore, if a given area of the West Bank is considered to have become part of Israel, most Palestinians subsequently born in such territory are plausibly entitled to receive Israeli citizenship as a matter of treaty law. There also seems to be a broad, emerging right under customary international law of the residents of a territory acquired by a state to receive the citizenship of that state, regardless of whether or not they would otherwise be considered stateless.

The West Bank is a territory under Israeli occupation, and annexation by an occupier of any part of the occupied territory violates international law. The Article argues, however, that the illegal annexation by Israel of an occupied territory would make that territory a part of Israel for the limited purpose of the right to citizenship, as an exception to the principle that illegal annexation is null and void. Hence, the existing and emerging IHRL obligations of Israel to grant citizenship to residents of territory acquired by
\end{abstract}

* Senior Lecturer, Ono Academic College. 
Israel extend to Palestinians residing in areas of the West Bank illegally annexed by Israel.

The Article argues further that, for the purpose of applying the norms of IHRL that concern the right to citizenship, the definition of annexation extends beyond formal annexation and encompasses de facto annexation as well. Annexation of occupied territory results from the occupier's display of sovereignty in that territory, among other things, by settling its own population in the occupied territory. In view of the current spread of Israeli settlements across the West Bank, unless Israel removes, within a reasonable time period, many of these settlements, the entire territory of the West Bank may be considered to have been annexed, and the entire Palestinian population of the West Bank would have a strong claim to Israeli citizenship under an emerging norm of international law. 


\section{TABLE OF CONTENTS}

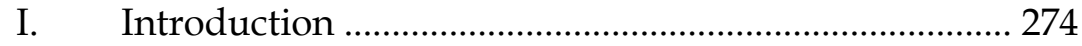

II. The Right to Citizenship and its Significance ............. 282

a. The Significance of Citizenship................................ 282

b. $\quad$ The Right to Acquire Citizenship .............................. 285

i. $\quad$ Traditional International Law ......................... 285

ii. The Universal Declaration of Human Rights and International Human Rights Treaties ............. 287

iii. Customary International Law .............................. 291

c. The Right to Citizenship and the Acquisition of Territory: Tuaua v. United States .............................. 296

d. Are West Bank Palestinians Stateless? ..................... 299

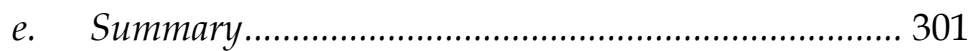

III. Illegal Annexation and the Right to Citizenship ......... 302

a. Illegal Annexation and the Obligation of NonRecognition ............................................................... 302

b. The Right of East Jerusalem Palestinians to Israeli Citizenship ............................................................. 310

IV. What Amounts to Annexation?..................................... 314

a. The Integration of Occupied Territory into Israel ...... 317

i. Facts on the Ground........................................ 317

ii. The Legal System ........................................... 320

b. The Parameters of de facto Annexation ..................... 324

i. $\quad$ The Purpose-Based Test for Annexation ......... 324

ii. $\quad$ The Effects-Based Test for Annexation............ 328

iii. $\quad$ The Display of Sovereignty Test for Annexation.

c. The Proposed Test for Annexation for the Purpose of the

Right to Citizenship. 332

d. The Annexation of West Bank Territories and the Character of Israel as a Jewish State ........................... 335

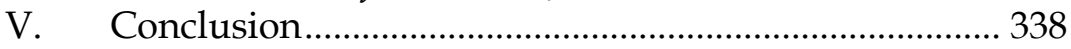




\section{INTRODUCTION}

In 2019, the Prime Minister of Israel, Benjamin Netanyahu, declared his intention to promote the formal annexation of parts of the West Bank, a territory occupied by Israel since 1967. ${ }^{1}$ The planned annexation would encompass many or all Israeli settlements located in the West Bank, but would not include Palestinian urban areas. ${ }^{2}$ In August 2020, Israel agreed to suspend its plan of formal annexation in order to normalize relations with the United Arab Emirates. ${ }^{3}$ The length of the announced suspension, and whether the annexation plan is carried out eventually, remains unclear. If it happens, formal annexation would merely be the culmination of five decades of Israeli annexationist policies throughout the West Bank, manifest in the enterprise of Israeli settlements in this territory. ${ }^{4}$ Much like the formal annexation plans, the settlement enterprise generally targets territories outside Palestinian population centers. ${ }^{5}$

\footnotetext{
1 Andrew Carey, Netanyahu Says Israel Will Annex Parts of West Bank if He is ReElected, CNN (Sept. 11, 2019), https://edition.cnn.com/2019/09/10/world/netanyahu-israel-west-bank-jordanvalley/index.html [https://perma.cc/H4K8-G538]; Oliver Holmes, Netanyahu Vows to Annex Jewish Settlements in Occupied West Bank, GuARDian (Apr. 7, 2019), https://www.theguardian.com/world/2019/apr/07/netanyahu-vows-to-annexe -jewish-settlements-in-occupied-west-bank [https:// perma.cc/2P45-CCGJ].

2 Oliver Holmes, Israel Signs Historic Deal with UAE that Will 'Suspend' West Bank Annexation, GUARDIAN (Aug. 13, 2020), https://www.theguardian.com/world/2020/aug/13/israel-and-uae-to-form-dip lomatic-ties-says-donald-trump [https://perma.cc/8RWK-QKH6] (citing a statement by Prime Minister Netanyahu regarding his intention to promote the annexation of all Israeli settlements in the West Bank). Formal annexation may also extend to the Jordan Valley (an area amounting to roughly twenty-two percent of the territory of the West Bank). See Carey, supra note 1; Data on Netanyahu's Jordan Valley Annexation Map, PEACE Now (Sept. 11, 2019), https:/ / peacenow.org.il/en/data-on-netanyahus-jordan-valley-annexation-map (citing Prime Minister Netanyahu's claim that no Palestinian would be annexed to Israel as a result of the planned annexation of the Jordan Valley).

3 Holmes, supra note 2.

4 See discussion of the settlement enterprise, infra Part IV.a.

5 A report by B'tselem, an Israeli human rights NGO, observes that the Oslo Accords, concluded between Israel and the Palestine Liberation Organization, divided the West Bank into three areas based on demographic considerations. The report proceeds to note that:
} 
While treating much of the occupied West Bank as its own, ${ }^{6}$ Israel has excluded the Palestinian population of this territory from its citizenry. Commentators have observed that the integration of West Bank territories into Israel through the settlements enterprise, coupled with the allocation of the benefits attached to Israeli citizenship only to Israel's own nationals but not to West Bank Palestinians, gives rise to flagrant discrimination that is tantamount to "the de facto institutionalization of Apartheid of some sort," 7 turning the occupation regime into one that "resembles a form of colonial regime." 8

This Article examines whether the annexationist policies of Israel in the West Bank have given rise, or will give rise in the near future, to a right of West Bank Palestinians to Israeli citizenship. This inquiry concerns mainly the vast majority of the Palestinian population of the West Bank, residing in urban areas that are not targeted by the settlement policy of Israel or by its plans of formal annexation.

The scope of the obligation of a state to confer citizenship on individuals is determined by international human rights law ("IHRL"). 9 Insofar as existing and emerging norms of IHRL recognize such an obligation, it is largely premised on a territorial

Under this division densely populated Palestinian areas were designated Areas $A$ and $B$ and then handed over - . . merely on paper - to the full or partial control of the Palestinian Authority. These areas are noncontiguous, constituting 165 'islands' scattered across the West Bank. The rest of the land, constituting some $60 \%$ of the West Bank, was designated Area $C$ and remained under full Israeli control. Area $C$ is contiguous and includes all Israeli settlements .... .

Conquer and Divide: The Shattering of Palestinian Space by Israel, B'TSELEM (2018), https://conquer-and-divide.btselem.org/map-en.html [https://perma.cc/G5N9P7Q6]. Israeli settlement enclaves within Palestinian urban areas exist only in East Jerusalem, which has been formally annexed by Israel, and in the Palestinian city of Hebron. See Settlements, B'TSELEM (Jan. 16, 2019), https://www.btselem.org/settlements [https://perma.cc/J6FX-FU4P].

6 See discussion of Israeli policies of integrating large parts of the West Bank into Israel, infra Part IV.a.

7 Orna Ben-Naftali, Aeyal M. Gross \& Keren Michaeli, Illegal Occupation: Framing the Occupied Palestinian Territory, 23 BERKELEY J. INT'L L. 551, 600 (2005); see also John Dugard \& John Reynolds, Apartheid, International Law, and the Occupied Palestinian Territory, 24 EUR. J. INT'L L. 867, 912 (2013).

8 Ben-Naftali, Gross \& Michaeli, supra note 7, at 586.

9 See discussion infra Part II.b. 
link between the state and the individual.10 The legal literature and the U.N. International Law Commission ("ILC") examined the application of these norms to the residents of a territory acquired by a state in the course of state succession. ${ }^{11}$ Situations of state succession include four modes of legal acquisition of territory, namely "transfer of part of the territory, unification of States, dissolution of a State and separation of part of the territory." 12

Yet, applying the norms of IHRL on citizenship to the relationship between Israel and West Bank Palestinians, based on the annexationist policies of Israel in the West Bank, is by no means straightforward. The West Bank is a territory under Israeli occupation. ${ }^{13}$ While situations of state succession concern the lawful acquisition of territory by a state, the unilateral annexation by an occupier of any part of the occupied territory violates international law. ${ }^{14}$ Such annexation is deemed by international law to be null and void, 15 and attaching to it any legal effect would stand in tension with this principle. Moreover, with the exception of East Jerusalem, the annexationist policies of Israel have not taken the form of formal annexation of West Bank territories, and such formal measure, if pursued in the future, is likely to exclude those parts of the West Bank populated by the bulk of the Palestinian population. ${ }^{16}$

The inquiry into whether, and to what extent, international law supports a claim by West Bank Palestinians to Israeli citizenship is threefold. First, this Article examines the scope of the obligation of Israel under IHRL to grant citizenship to the residents of a territory that is deemed by international law to have become part of Israel. This Article shows that a plausible reading of the IHRL treaty obligations of Israel in matters of citizenship suggests that Israel is

10 Int'l Law Comm'n, Rep. on the Work of Its Fifty-First Session, U.N. Doc. A/54/10, at 29 (Apr. 3, 1999) [hereinafter ILC Draft Articles on Nationality], https://legal.un.org/ilc/documentation/english/reports/a_54_10.pdf [https://perma.cc/CKJ4-VWWH].

11 See id; see also discussion infra Part II.b.

12 ILC Draft Articles on Nationality, supra note 10, at 23.

13 See Legal Consequences of the Construction of a Wall in the Occupied Palestinian Territory, Advisory Opinion, 2004 I.C.J. 136, ๆ 78 (July 9).

14 See infra notes 143-44 and accompanying text.

15 S.C. Res. 478, ๆ 2-3 (Aug. 20, 1980); YorAm DinsteIn, THE INTERNATIONAL LAW OF BELLIGERENT OCCUPATION 58-60 (2009).

16 See sources cited supra note 2. 
obligated to grant citizenship to individuals born in its territory, who would otherwise be stateless. The Article further demonstrates that most West Bank Palestinians are currently considered stateless. Therefore, if a given area of the West Bank is considered to have become part of Israel, most Palestinians subsequently born in such territory are plausibly entitled to receive Israeli citizenship as a matter of treaty law. In the case of legal annexation of territory by a state, there also seems to be an emerging right under customary international law of the residents of the annexed territory to receive the citizenship of the annexing state, regardless of whether or not such individuals would otherwise be considered stateless. The Article concludes, however, that this emerging customary right is yet to consolidate as lex lata.

Second, the Article examines whether the norms of IHRL on the right to citizenship in the case of lawful annexation also extend to the residents of territory that has been illegally annexed by Israel. In other words, would the illegal annexation by Israel of the West Bank make that territory a part of Israel for the purpose of the right to citizenship?

The Article shows that international law has recognized a limited human rights exception to the principle that an illegal annexation is null and void. The interests underlying this principle must, at times, be balanced against human rights, and the contours of this balancing have been delineated by international jurisprudence. Based on this jurisprudence, the Article concludes that the norms of IHRL on the right to citizenship, which apply to situations of state succession, extend to the case of illegal annexation as well. In other words, an occupied territory unlawfully annexed by the occupier may be viewed as part of the occupier's territory for the limited purpose of the right to citizenship. This conclusion suffices to determine that the obligations of Israel under the norms of IHRL on the right to citizenship apply, at the very least, to Palestinian residents of East Jerusalem, a territory that has been formally annexed by Israel. ${ }^{17}$

Third, the Article explores the concept of de facto annexation in relation to the question of citizenship. Should parts of the West Bank be considered, for the purpose of recognizing the right of Palestinian residents of these territories to Israeli citizenship, a part of Israel

17 See discussion infra Part III.b. 
based on a doctrine that extends the concept of annexation beyond formal annexation to encompass de facto annexation as well? The Article answers this question in the affirmative, arguing that states must not be allowed to evade their human rights obligations by resorting to formal representations that do not reflect reality regarding the status of a territory.

Commentators have pointed to "the doctrinal hole in the part of international law governing annexation," 18 which lacks "any existing legal test for identifying an annexation where the matter is unclear and in dispute." 19 The Article reviews the various possible tests for the existence of de facto annexation proposed by international jurisprudence and by the literature. For the purpose of the right to citizenship, the Article advances the display of sovereignty test for the existence of annexation, which brings together formal annexation and de facto annexation. The test is satisfied by the occupier's continuous exercise in the occupied territory of governmental functions that are typically reserved to a sovereign. In other words, the occupier's treatment of the occupied territory as its own. The clearest form of such a display of sovereignty is the full extension by the occupier of its legal and administrative systems to the occupied territory, which is the distinguishing mark of formal annexation. ${ }^{20}$ Yet, the occupier's treatment of the occupied territory as its own, which satisfies the display of sovereignty test for annexation, may also take the form of the settlement by the occupier of its own population within the occupied territory, large-scale infrastructure projects aimed at supporting such settlement activity, and a partial extension of the occupier's own legal system to the occupied territory. Reviewing the enterprise of Israeli settlements in the West Bank and the legal regime applied to it by Israel, the Article demonstrates that Israeli displays of sovereignty in the West Bank amount to annexation.

What is the territorial scope of this annexation? The main challenge in the application of the display of sovereignty test for annexation concerns efforts on the part of the occupier to design the

18 Joshua Kleinfeld, Skeptical Internationalism: A Study of Whether International Law is Law, 78 FordHAm L. ReV. 2451, 2498 (2010); see also Omar M. Dajani, Israel's Creeping Annexation, 111 AM. J. INT'L L. UnBOUND 51, 52 (2017-2018).

19 Kleinfeld, supra note 18, at 2495.

20 See infra notes 195-200 and accompanying text. 
map of annexation in accordance with demographic considerations. Israeli displays of sovereignty in the West Bank, manifest in the settlement enterprise, typically target territories outside Palestinian population centers, ${ }^{21}$ as do plans to formally annex parts of the West Bank. ${ }^{22}$ Does the scope of annexation extend to population centers within the occupied territory that are not the object of the occupier's annexationist policies, when the occupier aims to tailor its annexation of occupied territory around, and to the exclusion of, such population centers to advance a "maximum land, minimum population" annexation formula?

The Article maintains that the principle of legality in international law and the right to self-determination support an argument against allowing an occupier to pick and choose densely populated areas within the occupied territory that the occupier would exclude from the realm of annexation and thereby from the sway of the right to citizenship. Therefore, displays of sovereignty by the occupier in large parts of the occupied territory, in the form of formal annexation, settlement activity, or otherwise, may give rise also to annexation of other areas of the occupied territory, which are not targeted by the occupier's annexationist policies. In view of the current web of Israeli settlements across the West Bank, the proposed test for annexation leads to the conclusion that unless Israel removes, within a reasonable time, many of the settlements, the entire territory of the West Bank will be considered to have been annexed by Israel for the purpose of applying the norms of IHRL to a claim by West Bank Palestinians to Israeli citizenship.

Some international lawyers rely on the notion of illegal occupation as the preferred legal avenue for dismantling the type of colonial regime established in the West Bank. ${ }^{23}$ Illegal occupation gives rise to a duty of the occupier to withdraw from the occupied

21 See sources cited supra note 5 and accompanying text.

22 See Data on Netanyahu's Jordan Valley Annexation Map, supra note 2.

23 See Ben-Naftali, Gross \& Michaeli, supra note 7, at 605 (noting that the actions of Israel in the West Bank "amount to a de facto annexation of large portions of the occupied territory," and that the Israeli occupation of the West Bank is therefore illegal). Ben-Naftali, Gross and Michaeli caution that "[ $t$ ]he law of occupation may indeed pave the way for a kind of apartheid, but only to the extent that it will be interpreted as excluding the notion of illegal occupation." Id. at 611, n. 327. 
territory immediately and unconditionally. ${ }^{24}$ International law has long recognized the illegality of an occupation that was created by an unlawful use of force by the occupier. ${ }^{25}$ An emerging approach among commentators holds that an occupation resulting from a lawful use of force by the occupier-in self-defense ("lawfully created occupation") - may also become illegal. ${ }^{26}$ Proponents of this approach argue that the illegality of an occupation regime stems from the unreasonable prolongation by the occupier of the occupation. ${ }^{27}$ Arguments that such conduct on the part of the occupier renders the occupation illegal have largely focused on the occupation of the West Bank by Israel, which, by most accounts, resulted from the lawful use of force by Israel. ${ }^{28}$

The view that a lawfully created occupation may subsequently become illegal is highly disputed in the literature ${ }^{29}$ and does not find (2008)

24 Yael Ronen, Illegal Occupation and Its Consequences, 41 IsR. L. REv. 201, 228

25 See G.A. Res. 2625 (XXV), Declaration on Principles of International Law Concerning Friendly Relations and Cooperation among States in Accordance with the Charter of the United Nations, at 123 (Oct. 24, 1970) ("The territory of a State shall not be the object of military occupation resulting from the use of force in contravention of the provisions of the [U.N.] Charter."); see also Ariel Zemach, Can Occupation Resulting from a War of Self-Defense Become Illegal?, 24 MINN. J. INT'L L. 313, 323-24 (2015).

26 Ben-Naftali, Gross \& Michaeli, supra note 7, at 557; EyAl BenvEnISTI, THE INTERNATIONAL LAW OF OCCUPATION 16-17 (2d ed. 2012); ANTONIO CASSESE, SELFDetermination of PeOPles: A Legal ReApPRAisAl 55, 99 (1995); Ronen, supra note 24 , at 210, 218.

27 BENVENISTI, supra note 26, at 245-47; Ben-Naftali, Gross \& Michaeli, supra note 7, at 592-94, 597-605 (pointing to a "reasonable time" limit on the duration of occupation).

28 See, e.g., YORAM Dinstein, WAR, AgGRESSION AND SElF-DefENSE 206-207 (2011); Thomas M. FrancK, Recourse to Force: State ACtion Against Threats AND ARMED ATTACKS 104-05 (2002); CASSESE, supra note 26, at 131; GEOFFREY R. WATSON, THE OSLO ACCORDS: INTERNATIONAL LAW AND THE ISRAELI-PALESTINIAN Peace Agreements 30 (2000); George P. Fletcher, A Crime of Self-Defense: Bernhard Goetz AND the LaW ON Trial 20-21 (1988); Michael P. Scharf, Clear and Present Danger: Enforcing the International Ban on Biological and Chemical Weapons Through Sanctions, Use of Force, and Criminalization, 20 MicH. J. INT'L L. 477, 491-92 (1999).

29 See, e.g., DinSTEIN, supra note 15, at 2 ("A . . myth surrounding the legal regime of belligerent occupation is that it is, or becomes in time, inherently illegal under international law."); Michael Curtis, International Law and the Territories, 32 HARV. INT'L L.J. 457, 464-65 (1991) ("Israel is legally entitled to remain in the territory it now holds and to protect its security interests therein until new boundaries are 
sufficient support in state practice. ${ }^{30}$ Moreover, the significance of the illegality of occupation as a legal vehicle for facilitating the end of occupation, and thereby the termination of an occupier's annexationist policies, is diminished once the factual integration of the occupied territory into the occupying state is so deeply entrenched that it cannot realistically be reversed. Indeed, the purpose of an occupier's annexationist policies is to create such factual reality.

The notion of illegal occupation and a theory that links the annexation of an occupied territory to a right of its residents to the citizenship of the occupying state are competing ideas. The former concerns the end of occupation, and as a corollary, the termination of any formal or de facto annexation; the latter concerns the enjoyment of the fruits of annexation by residents of the occupied territory. Setting aside the controversy about whether or not a lawfully created occupation may become illegal, this Article explores the path in international law for recognizing a right of the residents of an occupied territory to the citizenship of the occupying state on the basis of annexation.

Part II of this Article discusses the significance of the right to citizenship. Unless otherwise indicated, the terms "citizenship" and "nationality" are used throughout the Article synonymously. ${ }^{31}$ Part II also elaborates on the scope of the obligations of Israel, under existing and emerging norms of IHRL, to grant citizenship to individuals residing in its territory, particularly following the acquisition of territory by Israel. Part III shows that such obligations extend to Palestinians residing in occupied territories illegally

drawn in a peace settlement."); Rosalyn Higgins, The Place of International Law in the Settlement of Disputes by the Security Council, 64 AM. J. INT'L L. 1, 8 (1970) (“[T]here is nothing in either the [U.N.] Charter or general international law which leads one to suppose that military occupation, pending a peace treaty, is illegal."); see generally Zemach, supra note 25, at 313 (arguing that the notion of illegal occupation in international law does not extend to occupation resulting from the lawful use of force by a state in self-defense).

30 Zemach, supra note 25, at 326-334 (demonstrating that international practice does not sufficiently support the existence of a rule of customary international law providing that a prolonged occupation resulting from a lawful use of force may become illegal).

31 Peter J. Spiro, A New International Law of Citizenship, 105 AM. J. INT'L L. 694, 717 (2011) (noting that many commentators consider "nationality" and "citizenship" interchangeable). 
annexed by Israel. Part IV reviews Israeli policies of integrating parts of the occupied West Bank into Israel, which so far have not taken the form of formal annexation. Part IV argues that, for the purpose of applying the norms of IHRL concerning the right to citizenship, the definition of annexation extends beyond formal annexation and encompasses de facto annexation. Part IV identifies the appropriate test for the existence of annexation and applies it to the occupied West Bank.

\section{THE RIGHT TO CITIZENSHIP AND ITS SIGNIFICANCE}

\section{a. The Significance of Citizenship}

The International Court of Justice ("ICJ") described nationality as a "legal bond" between an individual and a particular state. ${ }^{32}$ Commentators have identified two core consequences of nationality under customary international law. First, a state has a discretionary right, but not an obligation, to provide diplomatic protection to its nationals, that is, "to intervene on behalf of its own nationals if their rights are violated by another state for the purpose of obtaining redress." 33 Second, a state has a duty to admit and readmit its nationals into its territory and allow them to reside therein. ${ }^{34}$

Alice Edwards observed that beyond diplomatic protection and the duty of states to admit their citizens, "there is no agreed substantive minimum content of nationality as a matter of international law, not least because it turns so heavily on conditions and rules in the state of nationality." 35 According to Edwards, the right to nationality in international law is primarily a "procedural right, covering rights and rules relating to nationality acquisition

32 Nottebohm (Liech. v. Guat.), Judgment, 1955 I.C.J. 4, 23 (Apr. 6).

33 Alice Edwards, The Meaning of Nationality in International Law in an Era of Human Rights: Procedural and Substantive Aspects, in NATIONALITY ANDSTATELESSNESS UNDER INTERNATIONAL LAW 11, 30-31 (Alice Edwards \& Laura Van Waas eds., 2014); see also P. WEIS, NATIONALITY AND STATELESSNESS IN INTERNATIONAL LAW 32-44 (2d ed. 1979) (discussing the right of states to provide diplomatic protection to their nationals).

34 Edwards, supra note 33, at 30, 35-38; WEIS, supra note 33, at 45-49.

35 Edwards, supra note 33, at 42. 
and deprivation," 36 whereas "the substantive content of 'citizenship' will depend to a large extent on one's country of citizenship." 37

Edwards's observation may be accurate with respect to customary international law. Yet, treaty law that is binding on Israel entitles citizens, but not others, to the most important aspects of political participation. Article 25 of the International Covenant on Civil and Political Rights ("ICCPR") provides that every citizen has the right to "take part in the conduct of public affairs, directly or through freely chosen representatives[,]" vote in elections for the governing institutions of the state, and stand for election to such institutions. ${ }^{38}$ This provision also entitles citizens to have access to public service. ${ }^{39}$ Article 25 stipulates that these rights must be secured for all citizens without "unreasonable restrictions" or discrimination based on any status. ${ }^{40}$

The substantive significance of citizenship in international law also stems from the general human rights law principle of nondiscrimination, enshrined in numerous human rights instruments 41 and considered a norm of customary international law. ${ }^{42}$ As stated, among others, in Article 26 of the ICCPR, this norm provides that:

All persons are equal before the law and are entitled without any discrimination to the equal protection of the law. In this respect, the law shall prohibit any discrimination and guarantee to all persons equal and effective protection against discrimination on any ground such as race, colour,

36 Id. at 16 (internal quotations omitted).

37 Id. at 14.

38 International Covenant on Civil and Political Rights art. 25, Dec. 19, 1966, 999 U.N.T.S. 171 [hereinafter ICCPR].

39 Id. at 179.

40 Id.; see also id. at 173-74 (prohibiting discrimination based on any status in the application of the rights recognized in the ICCPR).

41 See, e.g., European Convention on Nationality art. 5(2), Nov. 6, 1997, 37 I.L.M. 44.; International Convention on the Elimination of All Forms of Racial Discrimination, Mar. 7, 1966, 660 U.N.T.S. 211; ICCPR, supra note 38, 999 U.N.T.S. at 179; G.A. Res. 217 (III) A, Universal Declaration of Human Rights, art. 2 (Dec. 10, 1948) [hereinafter UDHR].

42 See Steven D. Jamar, The International Human Right to Health, 22 S.U. L. REV. 1, 25 (1994) ("The right of non-discrimination and the right of equality are so well enshrined in all human rights conventions as to be an indisputable part of customary international human rights law."). 
sex, language, religion, political or other opinion, national or social origin, property, birth or other status. ${ }^{43}$

Applied to citizenship status, the principle of nondiscrimination entails that "[a]s a citizen/national, an individual is recognized as a full member of the state, with all its attendant rights and obligations to be enjoyed in full equality and without discrimination." 44 T.H. Marshall described citizenship as "a status bestowed on those who are full members of a community. All who possess the status are equal with respect to the rights and duties with which the status is endowed." 45

The relationship between citizenship and the principle of nondiscrimination, therefore, makes the former "the threshold through which individuals gain rights." 46 Chief Justice Warren's description of citizenship as the "right to have rights" 47 is only partially accurate when it comes to international human rights law, as there are fundamental human rights that a state must secure for individuals within its jurisdiction regardless of citizenship. 48 There is, however, a bundle of rights that, under international human rights law, flow from citizenship by virtue of the principle of non-discrimination, in that if the state grants them to some of its citizens it must extend them to all its citizens. Hence, in addition to political rights and the rights of entry and residence, citizenship status may bear on a range of social and economic rights, including the right to own property, the right to work, and the right to receive economic benefits afforded by the government only to citizens. ${ }^{49}$

43 ICCPR, supra note 38, 999 U.N.T.S. at 179.

44 Edwards, supra note 33, at 38.

45 T.H. Marshall, Citizenship and Social Class, in CitizenshIP AND Social Class 3, 18 (T.H. Marshall \& Tom Bottomore eds., 1992).

46 David M. Howard, Analyzing the Causes of Statelessness in Syrian Refugee Children, 52 TEX. INT'L L. J. 281, 286 (2017).

47 Trop v. Dulles, 356 U.S. 86, 102 (1958).

48 See Edwards, supra note 33, at 40 ("[W]hile international human rights law articulates the basic rights all persons are entitled to enjoy, regardless of their nationality, there are still some key rights linked to nationality.").

49 See Edwards, supra note 33, at 40 (noting that "rights to economic, social and cultural advancement" are generally associated with citizenship); Carol A. Batchelor, Statelessness and the Problem of Resolving Nationality Status, 10 INT'L J. $^{\prime}$ REFugEe L. 156, 159 (1998) ("Failure to acquire status under the law can have a negative impact on many important elements of life, including the right to vote, to 


\section{b. The Right to Acquire Citizenship}

\section{i. Traditional International Law}

The traditional approach followed by international law in matters of nationality, stated in Oppenheim's International Law, held that "it is not for international law but for the internal law of each state to determine who is, and who is not, to be considered its national." 50 This view was affirmed by the Permanent Court of International Justice in its advisory opinion concerning the Tunis and Morocco Nationality Decrees, which noted that "in the present state of international law, questions of nationality are, in the opinion of the Court, in principle within this reserved domain [of state discretion]." 51 This approach also prevailed with regard to the legal consequences of state succession. ${ }^{52}$

The deference of traditional international law to state discretion in matters of citizenship has not been absolute. The existence of modest international restraints on the liberty of states in this sphere was indicated in Article 1 of the Convention on Certain Questions Relating to the Conflict of Nationality Laws ${ }^{53}$ ("1930 Hague Convention"). The Convention reaffirmed the traditional view that "[i]t is for each State to determine under its own law who are its nationals," 54 but proceeded to stipulate that nationality laws enacted by a state "shall be recognized by other States in so far as it is consistent with international conventions, international custom, and

own property, to have health care, to send one's children to school, to work, and to travel to and from one's country of residence."); Howard, supra note 46, at 286.

501 Oppenheim's International Law: PeAce 852 (Robert Jennings \& Arthur Watts eds., 9th ed. 2008).

51 Second (Extraordinary) Session, Advisory Opinion No. 4, 1923 P.C.I.J. (ser. B) 7, 24 (Feb. 7).

52 See Jeffrey L. Blackman, State Successions and Statelessness: The Emerging Right to an Effective Nationality under International Law, 19 MicH. J. INT'L L. 1141, 1152 (1998) ("In the context of state succession, the traditional view holds that the nationality of individuals affected by a change in sovereignty must be determined by the domestic law of the states concerned.").

53 See Convention on Certain Questions Relating to the Conflict of Nationality Laws art. 1, Apr. 12, 1930, 179 L.N.T.S. 89 [hereinafter Hague Convention on Nationality].

54 Id. art. 1. 
the principles of law generally recognized with regard to nationality." 55 It was thus observed that the 1930 Hague Convention "simultaneously asserts the principle of state discretion over nationality questions and the principle of international limitations on state discretion-without specifying what those limitations might be." 56

It seems, however, that prior to the development of international human rights law, customary international law imposed only negative limitations on state discretion in matters of citizenship. These limitations provided that a state cannot claim that its conferring of citizenship on an individual is entitled to recognition by other states in the absence of sufficient factual ties between that state and the individual concerned. ${ }^{57}$ International law restraints on state discretion in matters of citizenship did not take the form of positive citizenship rights that individuals possess with respect to a particular state. 58

55 Id.

56 Blackman, supra note 52, at 1154.

57 Nottebohm (Liech. v. Guat.), Judgment, 1955 I.C.J. 4, 22-26 (Apr. 6). This case involved a claim for damages filed by Liechtenstein against Guatemala on behalf of Nottebohm, a resident of Guatemala who was granted citizenship by Liechtenstein. The International Court of Justice ("ICJ") held that Guatemala was under no obligation to recognize the citizenship granted by Liechtenstein to Nottebohm, and that Liechtenstein, therefore, was not entitled to exercise diplomatic protection in respect of Nottebohm. The Court reasoned that the granting of citizenship did not reflect real and effective ties between Liechtenstein and Nottebohm, and that a state's policy with regard to the granting of citizenship merits recognition by other states only if "it has acted in conformity with [the] general aim of making the legal bond of nationality accord with the individual's genuine connection with the State." Id. See also Spiro, supra note 31, at 705 ("Nottebohm was merely an extension of the accepted rule that states could not reach out to claim those to whom they had no real connection."); Blackman, supra note 52, at 1158 ("In relation to nationality law, then, the international limitations on state discretion affirmed in Nottebohm remained negative in character, taking the form of non-recognition by other international subjects.").

58 See Spiro, supra note 31, at 698 ("The early law of nationality was bounded by the interests of states vis-a-vis each other, not the interests of individuals."); Blackman, supra note 52, at 1158 (noting that in Nottebohm "the Court [did not] assert any dramatic positive rights of individuals with respect to nationality claims viz. states."). 
ii. The Universal Declaration of Human Rights and International Human Rights Treaties

The right to a nationality was introduced into the sphere of international law in 1948 by Article 15 of the Universal Declaration of Human Rights ("UDHR"), which provided that:

1. Everyone has the right to a nationality.

2. No one shall be arbitrarily deprived of his nationality nor denied the right to change his nationality. ${ }^{59}$

The positive character of Article 15 has been disputed in the literature. It has been argued that "the article's vagueness has robbed it of any immediate force. Most significantly, Article 15 does not carry a specific corresponding obligation on states to confer nationality. In other words, the article fails to indicate precisely to which nationality one has the right and under what circumstances that right arises." 60

The ICCPR, an instrument intended to give legal effect to the UDHR, does not include any reference to a general right to nationality. Commentators reviewing the drafting history of the ICCPR have attributed this omission to the complexity of developing rules for the realization of the general principle stated in the UDHR. ${ }^{61}$ Article 24(3) of the ICCPR, which concerns the rights of children, states that "[e]very child has the right to acquire a nationality." 62 The right of children to acquire a nationality was also recognized by Article 7 of the Convention on the Rights of the Child ("Child Convention"), which stipulates:

59 UDHR, supra note 41, art. 15(1)-(2).

60 Blackman, supra note 52, at 1172 (internal italics omitted); see also Edwards, supra note 33, at 14 ("No corresponding obligation on states to grant nationality was elaborated in the UDHR.").

61 See, e.g., Johannes M.M. Chan, The Right to a Nationality as a Human Right, 12 HuM. RTS. L.J. 1, 4-5 (1991).

62 ICCPR, supra note 38, 999 U.N.T.S. at 179. Similarly, according to principle 3 of the Declaration of the Rights of the Child, adopted by the U.N. General Assembly, " $\mathrm{t}$ ] he child shall be entitled from his birth to a name and a nationality." G.A. Res. 1386 (XIV), Declaration of the Rights of the Child, Prin. 3 (Dec. 10, 1959). 
1. The child shall be registered immediately after birth and shall have the right from birth to a name, [and] the right to acquire a nationality ...

2. States Parties shall ensure the implementation of these rights in accordance with their national law and their obligations under the relevant international instruments in this field, in particular where the child would otherwise be stateless. 63

These instruments do not explicitly identify which state bears the corresponding obligation to grant citizenship. ${ }^{64}$

Article 2(1) of the Child Convention, however, requires states to respect and ensure the rights enunciated in the Convention "to each child within their jurisdiction without discrimination." 65 Based on a joint reading of Article 7 and Article 2(1) of the Child Convention, the ILC construed this instrument to require that "unless the child acquires the nationality of another State, he or she has, in the last instance, the right to the nationality of the State on the territory of which he or she was born." 66 A similar construction may be applied to Article 24(3) of the ICCPR, in view of Article 2(1) of the ICCPR, which requires states to respect and ensure the rights enunciated in this instrument "to all individuals within [their] territory and subject to [their] jurisdiction." 67

This construction of Article 24(3) of the ICCPR and of Article 7 of the Child Convention is not shared by everyone, however. In its General Comment No. 17, which addressed the construction of Article 24 of the ICCPR, the United Nations Human Rights Committee ("UNHRC") did not identify which state bears the obligation to grant a child citizenship to prevent statelessness or

63 Convention on the Rights of the Child art. 7, Nov. 20, 1989, 1577 U.N.T.S. 3 [hereinafter Child Convention].

64 See Gerard-René de Groot, Children, Their Right to a Nationality and Child Statelessness, in NATIONALITY AND STATELESSNESS UNDER INTERNATIONAL LAW 144, 146 (Alice Edwards \& Laura Van Waas eds., 2014) ("Neither the ICCPR nor the CRC [Child Convention] indicate which nationality a child may have a right to ....").

65 Child Convention, supra note 63, 1577 U.N.T.S. at 46.

66 ILC Draft Articles on Nationality, supra note 10, at 36, cmt. 2.

67 ICCPR, supra note 38, 999 U.N.T.S. at 173. 
otherwise. 68 Jeffrey Blackman argued that Article 24(3) of the ICCPR, granting children a right to nationality, "is undermined by the failure to specify upon whom a corresponding obligation to grant nationality falls," 69 in the same way that Article 15 of the UDHR is undermined by its own vagueness. This view seems to pertain to Article 7 of the Child Convention, as well.

Article 1(1) of the 1961 Convention on the Reduction of Statelessness states that "[a] Contracting State shall grant its nationality to a person born in its territory who would otherwise be stateless." 70 "Statelessness is ... the legal condition of being without a nationality." 71 The Convention on the Reduction of Statelessness provides the clarity that is absent from the ICCPR and Child Convention, by explicitly identifying the state in which a stateless person was born as the bearer of the obligation to grant citizenship.

Israel is party to the ICCPR and to the Child Convention. ${ }^{72}$ Hence, under human rights treaty law, Israel arguably has an

68 United Nations Hum. Rts. Comm., General Comment No. 17: Rights of the Child (Article 24), sec. 8, U.N. Doc. HRI/GEN/1/Rev.6 (Apr. 7, 1989).

69 Blackman, supra note 52, at 1172.

70 Convention on the Reduction of Statelessness art. 1(1), Aug. 30, 1961, 989 U.N.T.S. 175 [hereinafter Statelessness Convention]. The Convention allows a state to determine whether nationality is granted "(a) at birth, by operation of law, or (b) upon an application being lodged with the appropriate authority." Id. See also id. art. 1(2) (A state that opts for the grant of nationality upon an application must allow the person concerned to submit such application within the period between her eighteenth birthday and her twenty-first birthday, and may require, as conditions for the grant of its nationality: (a) "that the person concerned has habitually resided in the territory of the State for such period as may be fixed by that State, not exceeding five years immediately preceding the lodging of the application nor ten years in all;" (b) "that the person concerned has neither been convicted of an offence against national security nor has been sentenced to imprisonment for a term of five years or more on a criminal charge;" and (c) "that the person concerned has always been stateless.").

71 Blackman, supra note 52, at 1176; see also Convention Relating to the Status of Stateless Persons art. 1, Sept. 28, 1954, 360 U.N.T.S. 117 ("The term 'stateless person' means a person who is not considered as a national by any State under the operation of its law.").

72 Covenant on Civil and Political Rights, Status of Treaties, Depositary, UnITED NATIONS TREATY COLLECTION, https:/ / treaties.un.org/Pages/ViewDetails.aspx?chapter=4\&clang=_en\&mtdsg_n $\mathrm{o}=\mathrm{IV}-4 \& \mathrm{src}=\mathrm{IND}$ [https://perma.cc/R8X8-BKKR]; Convention on the Rights of the Child, Status of Treaties, Depositary, United NATIONS TREATY COLleCtion, https://treaties.un.org/pages/ViewDetails.aspx?src=IND\&mtdsg_no=IV-11\&cha pter=4\&lang=en [https:/ / perma.cc/B69Z-UAMJ]. 
obligation to grant citizenship to children, born in its territory, who would otherwise remain stateless. Even this limited obligation is contingent upon a reading of the ICCPR and of the Child Convention that is not shared by everyone. Israel is not a party to the Convention on the Reduction of Statelessness ${ }^{73}$ nor to any regional human rights treaty that recognizes a right to nationality. ${ }^{74}$

The norm of non-discrimination, enshrined in IHRL treaty provisions, also bears on the obligations of Israel to grant citizenship. ${ }^{75}$ Article 26 of the ICCPR prohibits the discriminatory treatment of individuals based on race, religion, or national origin, among other things. ${ }^{76}$ Although the ICCPR does not stipulate a general right to citizenship, "[o]n the face of Article 26, the provisions for equality and non-discrimination are not confined in application to the rights set forth in the Covenant,"77 and therefore apply to the granting of citizenship, as well. The International Convention on the Elimination of All Forms of Racial Discrimination, to which Israel is a party, also guarantees the right of everyone, without distinction as to race, color, or national or ethnic origin, to equality before the law in the enjoyment of the right to nationality. 78

73 Convention on the Reduction of Statelessness, Status of Treaties, Depositary, United NATIONS TREATY COLlection (indicating that Israel has signed the Convention but has not ratified it), https://treaties.un.org/Pages/ViewDetails.aspx?src=TREATY\&mtdsg_no=V-4\&c hapter=5\&clang=_en [https://perma.cc/7C6K-G8E8].

74 See, e.g., American Convention on Human Rights art. 20(2), Nov. 22, 1969, O.A.S.T.S. No. 36, 1144 U.N.T.S. 123 ("Every person has the right to the nationality of the state in whose territory he was born if he does not have the right to any other nationality."); see also European Convention on Nationality, supra note 41, arts. 4, 6 (affirming the principles that "everyone has the right to a nationality" and that "statelessness shall be avoided," and stipulating the rules on nationality that derive from these principles).

75 See Spiro, supra note 31, at 721 ("[I]n the context of both state succession and migration, antidiscrimination norms supply an important baseline."); see also Edwards, supra note 33, at 26 ("[N]on-discrimination in nationality laws is a general principle of international law underpinned by many international conventions.").

76 ICCPR, supra note 38, 999 U.N.T.S. 179; see also supra text accompanying note 43 .

77 See Blackman, supra note 52, at 1184.

78 International Convention on the Elimination of All Forms of Racial Discrimination, supra note 41, 660 U.N.T.S. at 220; see also International Convention 
The Citizenship Law enacted by Israel allows a path to citizenship based on habitual residence, requiring, among other conditions, that individuals lawfully reside in Israel for three of the five years preceding the application for citizenship. ${ }^{79}$ In view of the principle of non-discrimination, in granting citizenship based on habitual residence, Israel must not discriminate against Palestinian residents of West Bank territories that are deemed a part of Israel. To the extent that a large number of West Bank Palestinians are considered to be its residents, Israel may choose, however, to repeal the habitual residence path to citizenship altogether. Importantly, the Israeli Law of Return entitles Jews and their descendants, but not others, to acquire Israeli citizenship without establishing habitual residence in Israel before applying for citizenship. ${ }^{80}$ The question of whether the ethnically-based discrimination manifest in the Law of Return can be justified, in view of the harsh history of the Jewish people, as an affirmative action exception to the norm of nondiscrimination, was debated extensively in legal literature. ${ }^{81}$

\section{iii. Customary International Law}

In view of the limited and disputed nature of the treaty law obligations of Israel in matters of nationality, it is important to examine whether the annexation of territory by a state gives rise to a broader and clearer obligation of that state under customary international law to confer citizenship upon the residents of the annexed territory. This question was discussed in the legal literature as well as by the ILC in relation to state succession.

\footnotetext{
on the Elimination of All Forms of Racial Discrimination, Status of Treaties, Depositary, UNITED NATIONS TREATY COLLECTION, https://treaties.un.org/Pages/ViewDetails.aspx?src=TREATY\&mtdsg_no=IV-2\& chapter $=4 \& c l a n g=$ en $[$ https: $/ /$ perma.cc/636V-HC6B].

79 See § 5(a), Citizenship Law, 5712-1952, LSI 650 (1951-52), as amended (Isr.).

80 Law of Return, 5710-1950, LSI 4114 (1950), as amended (Isr.); see also Jonathan Zasloff, Left and Right in the Middle East: Notes on the Social Construction of Race, 47 VA. J. INT'L L. 201, 207 (2006) (“Israel's 'Law of Return,' enacted just a few months after the founding of the state, explicitly grants automatic citizenship to anyone deemed Jewish under the criteria set forth in the law.").

81 For a review of this debate, see, e.g., Zasloff, supra note 80, at 207-210; Yehiel S. Kaplan, Immigration Policy of Israel: The Unique Perspective of a Jewish State, 31 TOURO L. REV. 1089, 1092-98, 1134 (2015).
} 
According to Ian Brownlie, a state that gained territory through change of sovereignty is required to grant citizenship to the residents of such territory. 82 Brownlie observed that state practice in situations of succession of states, examined as evidence of customary international law, "is overwhelmingly in support of the view that the population follows the change of sovereignty in matters of nationality." 83 This view finds support in the position adopted by international organizations involved in recent state successions. ${ }^{84}$

A similar position has been taken by the ILC in its Draft Articles on Nationality of Natural Persons in Relation to the Succession of States ${ }^{85}$ ("Draft Articles"). Article 1 of the Draft Articles stipulates that "[e]very individual who, on the date of the succession of States, had the nationality of the predecessor State, irrespective of the mode of acquisition of that nationality, has the right to the nationality of at least one of the States concerned, in accordance with the present draft articles." 86 The ILC noted that Article 1 is based on the principle, enshrined in Article 15 of the UDHR, according to which everyone has the right to a nationality, although it acknowledged that "the positive character of article 15 has been disputed in the doctrine." 87

In assigning the obligation corresponding to the right to nationality, the ILC resorted to the concept of "effective nationality,"

82 Ian Brownlie, The Relations of Nationality in Public International Law, 39 BRIT. Y.B. INT'L L. 284, 320-26 (1963).

83 Id. at 320.

84 See, e.g., ORG. FOR SEC. \& COOP. IN EUR., THE OtTAWA DeClaration OF THE OSCE PARLIAMENTARY ASSEMbly đ 34 (July 4-8, 1950), https://www.osce.org/pa/38133?download=true [https://perma.cc/4M88GADM] ("The OSCE Parliamentary Assembly, ... [u]rges that, upon a change in sovereignty, all persons who have a genuine and effective link with a new State should acquire the citizenship of that State."); EUROPEAN COMMISSION FOR DeMOCRACY THROUgh LAW, Venice COMMISSION DEClaration ON THE CONSEQUENCES OF STATE SUCCESSION FOR THE NATIONALITY OF NATURAL PERSONS art.

8 (Sept. 13-14, 1996), https://www.legislationline.org/documents/id/7960 [https://perma.cc/W6SS-8C8E] ("In all cases of State succession, the successor State shall grant its nationality to all nationals of the predecessor State residing permanently on the transferred territory."); European Convention on Nationality, supra note 41 , art. $18(2)$.

85 ILC Draft Articles on Nationality, supra note 10.

86 Id. at 25, art. 1.

87 Id. at 25, cmt. 1-2. 
which focuses on a territorial nexus between the state and the individual, in the form of habitual residence. 88 The ILC reasoned that "[h]abitual residence is the test that has most often been used in [state] practice for defining the basic body of nationals of the successor State, even if it was not the only one." 89 The ILC adhered to the view that "the juridical relationship of nationality should not be based on formality or artifice, but on a real connection between the individual and the State." 90 Article 20 of the Draft Articles therefore concludes that " $[\mathrm{w}]$ hen part of the territory of a State is transferred by that State to another State, the successor State shall attribute its nationality to the persons concerned who have their habitual residence in the transferred territory and the predecessor State shall withdraw its nationality from such persons," unless the individuals concerned opt to retain the nationality of the predecessor state. ${ }^{91}$ Similarly, Article 21 of the Draft Articles stipulates that when two or more States unite to form one successor state "the successor State shall attribute its nationality to all persons who, on the date of the succession of States, had the nationality of a predecessor State." 92 Moreover, based on the ILC's interpretation of the Child Convention regarding the right of a child to nationality, Article 13 of the Draft Articles states that "[a] child ... born after the date of the succession of States, who has not acquired any nationality, has the right to the nationality of the State concerned on whose territory that child was born." 93

The bulk of authority in the legal literature, however, does not support the view that the principles laid out by the ILC have consolidated the status of customary international law. D.P. $\mathrm{O}^{\prime}$ Connell concluded that " $[\mathrm{u}]$ ndesirable as it may be that any persons become stateless as a result of a change of sovereignty, it cannot be asserted with any measure of confidence that

88 Id. at 29, cmt. 4; see also Václav Mikulka (Special Rapporteur), Third Report on Nationality in Relation to the Succession of States, U.N. Doc. A/CN.4/480 (Feb. 2728 , 1997) ("The identification of the rules governing the distribution of individuals among the States involved in a succession derives in large part from the application of the principle of effective nationality to a specific case of State succession.").

89 ILC Draft Articles on Nationality, supra note 10, at 29, cmt. 4.

$90 \quad$ Id.

91 Id. at 41, art. 20.

92 Id. at 41-2, art. 21.

93 Id. at 35, art. 13. 
international law, at least in its present stage of development, imposes any duty on the successor State to grant nationality." 94 Similarly, Paul Weis concluded based on an extensive review of state practice:

[T] here is no rule of international law under which the nationals of the predecessor State acquire the nationality of the successor State. International law cannot have such a direct effect, and the practice of States does not bear out the contention that this is inevitably the result of the change of sovereignty. ${ }^{95}$

Acknowledging that "the overwhelming weight of state practice has been for a successor state to confer nationality on the nationals of the predecessor state domiciled on the territory concerned," 96 Jeffrey Blackman nevertheless maintained that such state practice "lacks the essential element under international law of opinio juris... no evidence demonstrates that states have conferred nationality in compliance with perceived international legal obligations to that effect." 97 Blackman concluded that "the right to nationality is probably not part of customary international law, given the few international instruments which mention the right and the absence of uniform state practice and opinio juris." 98 Recent literature seems to confirm this view. ${ }^{99}$

941 D.P. O'CONNELl, State Succession In Municipal LaW AND INTERNATIONAL LAW 503 (1967).

95 WEIS, supra note 33, at 143-44 ("As a rule, however, States have conferred their nationality on the former nationals of the predecessor State, and in this regard one may say that there is, in the absence of statutory provisions of municipal law, a presumption of international law that municipal law has this effect.").

96 Blackman, supra note 52, at 1163.

97 Id. In this regard, Blackman noted that the deliberations of the International Law Commission [hereinafter ILC] concerning the Draft Articles do not demonstrate a general agreement that the Draft Articles reflect lex lata. See id. at 1165; see also Václav Mikulka, Second Rep. on State Succession and Its Impact on the Nationality of Natural and Legal Persons, at 129, U.N. Doc. A/CN.4/474 (1996) (“[T]he comments of delegations [in the course of ILC discussions] were inconclusive as to the existence of an international obligation binding upon the successor State regarding the granting of its nationality following State succession.").

98 Blackman, supra note 52, at 1176.

99 Spiro, supra note 31, at 695-96 ("It is still not possible, however, to speak generally of a 'right to citizenship' (at least not one enforceable on particular states), 
Based on the ILC Draft Articles, the approach taken by international organizations and international treaties, Blackman recognized, however, that "the clear trend in international law is toward the imposition of positive obligations on states [with regard to the granting of citizenship] deriving from the principle of effective nationality . . . at least in the context of state successions." 100 Although the status of the right to nationality as lex lata is yet to consolidate, Blackman and others consider it to be "an emerging right" 101 that, upon state succession, will entitle individuals to nationality "in that state with which an individual possesses genuine and effective links." 102 Similarly, there are divergent views in the literature on whether the right of children, who would otherwise be stateless, to acquire the nationality of their state of birth has already been consolidated in customary international law or whether it is considered an emerging right. ${ }^{103}$

and it remains difficult even to speak of a right to citizenship in particular cases. The trend in practice is not a concerted or broadly conscious one and would not satisfy traditional doctrinal standards for establishing customary law."); Ineta Ziemele, State Succession and Issues of Nationality and Statelessness, in NATIONALITY AND STATELESSNESS UNDER INTERNATIONAL LAW 217, 245 (Alice Edwards \& Laura Van Waas eds., 2014) ("The fact remains that despite multiple reaffirmations of the right to nationality as a human right in different international law and human rights texts, the right to a specific nationality has not evolved."); Id. at 243 ("[I]t is difficult to say that there is a clear obligation as a matter of customary international law to avoid statelessness in each and every case.").

100 Blackman, supra note 52, at 1170.

101 Id. at 1192; see also Spiro, supra note 31, at 720-21 ("[An emerging norm of IHRL] holds that habitual residents and their progeny should not be relegated to noncitizen status indefinitely and that at some point in time, territorial presence should give rise to baseline eligibility for citizenship acquisition."). Spiro further notes that state practice supports this norm "[i]n the context of state succession perhaps more than any other." Id. at 721.

102 Blackman, supra note 52, at 1192.

103 Ziemele, supra note 99, at 243 ("[E]xceptionally in relation to children, the obligation not to render them stateless combined with the acknowledged right to acquire nationality at birth can be considered as having achieved the necessary opinion juris under customary international law and most likely applies irrespective of the lawful or unlawful context of territorial change."). But see Edwards, supra note 33, at 29 ("[T] he duty to prevent statelessness, at least in respect of children, is emerging as a norm of customary international law." (emphasis added)); de Groot, supra note 64, at 148 ("[W]ithin the realm of human rights law, there is broad recognition of the child's right to acquire a nationality," but there is "limited guidance on how the right is to be exercised."). 
c. The Right to Citizenship and the Acquisition of Territory: Tuauav. United States

The U.S. Court of Appeals for the District of Columbia has recently addressed a claim to citizenship rights emanating from the acquisition by the United States of the territory of American Samoa, a portion of a South Pacific archipelago that came under U.S. sovereignty in the early 20th Century. ${ }^{104}$ American Samoa has not been incorporated into the United States federal system. The territory is partially self-governed by a democratically elected government, but remains under the ultimate supervision of the U.S. Secretary of the Interior. ${ }^{105}$ The Immigration and Nationality Act of 1952,106 passed by the U.S. Congress, designates persons born in American Samoa as "non-citizen nationals" of the United States. ${ }^{107}$ In Tuaua v. United States, the Appellants, individuals born in American Samoa, claimed that they were entitled to U.S. citizenship by birthright, based on the Citizenship Clause of the Fourteenth Amendment to the U.S. Constitution, 108 which provides that "[a]11 persons born or naturalized in the United States, and subject to the jurisdiction thereof, are citizens of the United States and of the State wherein they reside." 109

Having concluded that "the Citizenship Clause is textually ambiguous as to whether 'in the United States' encompasses America's unincorporated territories," 110 the Court resorted to the doctrine laid out in the Insular Cases, a series of U.S. Supreme Court decisions that examined the reach of the Constitution in territories possessed by the United States that are not a part of the federal system of states. 111 This doctrine distinguishes between incorporated territories, which are designated for statehood from the time of acquisition, and unincorporated territories (such as

\footnotetext{
104 Tuaua v. United States, 788 F.3d 300, 302 (D.C. Cir. 2015).

105 See id.

106 The Immigration and Nationality Act of 1952, Pub. L. No. 82-414, 66 Stat.

107 Tuaua, 788 F.3d at 302; see also 8 U.S.C. § 1408(1).

108 Tuaua, 788 F.3d. at 302.

109 U.S. CONST. amend. XIV, § 1, cl. 1.

110 Tuaua, 788 F.3d at 302.

111 See, e.g., Reid v. Covert, 354 U.S. 1, 75, 77 (1957).
} 163 (1952). 
American Samoa), which are not designated for statehood. Whereas the Constitution applies with full force to the former, 112 the application of any particular constitutional protection to unincorporated territories depends on a case-by-case determination that the extension of the right to a particular unincorporated territory would not be "impractical and anomalous." 113 Such a determination must be made "in view of the particular circumstances, the practical necessities, and the possible alternatives which Congress had before it." 114 The reasoning in Tuaua therefore focused on examining "whether the circumstances are such that recognition of the right to birthright citizenship would prove 'impracticable and anomalous,' as applied to contemporary American Samoa." 115 The Court answered this question in the affirmative, and therefore concluded that the Citizenship Clause does not extend a right to U.S. citizenship to those born in American Samoa. ${ }^{116}$

The Court grounded its decision in the principles of democracy and self-determination. The democratically elected government of American Samoa joined the United States in opposing the appellants' claim to a constitutional birthright to citizenship. ${ }^{117}$ Speaking for the majority of its constituency, the government of American Samoa expressed concerns that the application of the Fourteenth Amendment to the U.S. Constitution to American Samoa could undermine "social structures inherent to the traditional Samoan way of life," 118 for example, "by imperiling American Samoa's traditional, racially-based land alienation rules." 119 The Court considered it "anomalous to impose citizenship over the objections of the American Samoan people themselves, as expressed through their democratically elected representatives."120 Citing the

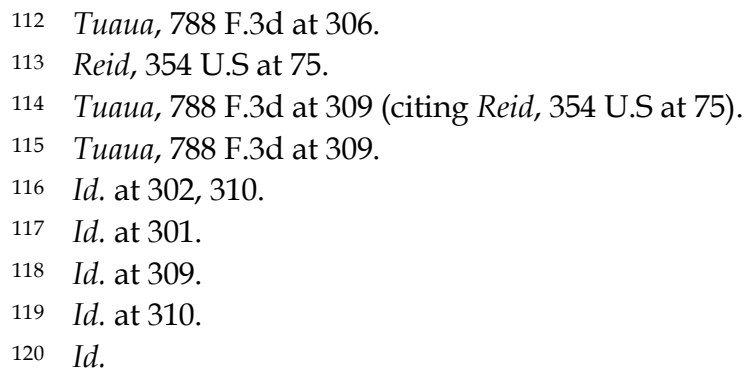


right of peoples to self-determination, enshrined in the United Nations Charter, 121 the Court elaborated:

We can envision little that is more anomalous, under modern standards, than the forcible imposition of citizenship against the majoritarian will ... . To hold the contrary would be to mandate an irregular intrusion into the autonomy of Samoan democratic decision-making; an exercise of paternalism - if not overt cultural imperialism-offensive to the shared democratic traditions of the United States and modern American Samoa. ${ }^{122}$

The reasoning of the Court did not address the right to citizenship in international human rights law, either in the interpretation of the constitutional Citizenship Clause or as an independent legal principle, outside the scope of the Citizenship Clause. This may be reasonably explained by the Court adhering to the position pronounced by a U.S. District Court judge six decades earlier, which holds that "citizenship depends . . . entirely on municipal law and is not regulated by international law. Acquisition of citizenship of the United States is governed solely by the Constitution and by acts of Congress." 123 Yet Tuaua has limited weight in assessing the state of IHRL on the right to citizenship, as the unique circumstances of the case stray far from the typical situations of acquisition of territory by a state envisioned in the ILC Draft Articles.

American Samoa, which maintains a high degree of autonomy, is governed by a democratically elected legislature and governor. ${ }^{124}$ This allows American Samoans to enjoy, in American Samoa, the

121 U.N. Charter arts. 1, 73; Tuaua, 788 F.3d at 311.

122 Tuaua, 788 F.3d at 311-12.

123 Tomasicchio v. Acheson, 98 F.Supp. 166, 169 (D.D.C. 1951).

124 For the extent of autonomy exercised by American Samoa, see, e.g., Office of Insular Affairs, American Samoa, U.S. DEP'T OF THE INTERIOR, https://www.doi.gov/oia/islands/american-samoa [https://perma.cc/YF6KSEM9] ("The Immigration and Naturalization Service of the U.S. Department of Justice does not exercise jurisdiction in American Samoa. No one may enter American Samoa unless he or she complies with certain entry requirements of the American Samoa Government."). Moreover, American Samoa has its own land ownership laws, which are not subject to the requirements of the U.S. Constitution. See Tuaua, 788 F.3d at 309-312; see also id. at 302 (noting the democratic nature of the government of American Samoa). 
rights typically associated with citizenship, including the right to democratic participation. According to the elected representatives of the people of American Samoa, the legal regime that applies to the territory is preferred by the majority of American Samoans. ${ }^{125}$ American Samoans are entitled to U.S. passports ${ }^{126}$ and presumably treated by the U.S. government not differently from U.S. citizens when it comes to diplomatic protection. American Samoans, therefore, appear to enjoy the equivalent of citizenship in a democratic state, although they do not enjoy all the particular benefits of U.S. citizenship, dubbed by the U.S. Supreme Court "one of the most valuable rights in the world today." 127

The arguments of democracy and self-determination against the granting of citizenship, which emanate from the special, highly autonomous status of American Samoa, are unavailable in typical situations of state succession, where the transferred territory is fully integrated into the successor state. The self-determination argument invoked by the Court against the granting of citizenship to American Samoans would ring particularly hollow when it comes to the reality of de facto annexation by an occupier of the occupied territory, which suppresses the exercise of the right to selfdetermination by the local population.

\section{d. Are West Bank Palestinians Stateless?}

To the extent that treaty provisions that are binding on Israel in matters of nationality, namely, Article 24(3) of the ICCPR and Article 7 of the Child Convention, require Israel to grant citizenship to individuals born in territory it has annexed, such requirement is confined to those who would otherwise be stateless. ${ }^{128}$ It seems that

125 Tuaua, 788 F.3d at 309-12.

126 Joseph E. Sung, Redressing the Legal Stigmatization of American Samoans, 89 S. CAL. L. REV. 1309, 1310 (2016).

127 Kennedy v. Mendoza-Martinez, 372 U.S. 144, 160 (1963).

128 See supra notes 62-67 and accompanying text. 
most West Bank Palestinians are considered stateless for the purpose of the application of IHRL in matters of nationality. ${ }^{129}$

In 1950, during the period of Jordanian occupation of the West Bank, Jordan declared the annexation of the West Bank. ${ }^{130}$ Shortly after the annexation, which was considered illegal and void by the bulk of the international community, ${ }^{131}$ Jordan granted Jordanian citizenship to the residents of the West Bank, pursuant to the Jordanian Nationality Law of 1954. ${ }^{132}$ In 1988, however, two decades after the beginning of the Israeli occupation of the West Bank, Jordan terminated its annexation of the West Bank, renounced its sovereignty claim to this territory, and divested the residents of the West Bank of their Jordanian citizenship. ${ }^{133}$ This last measure was undertaken in the form of government instructions, which stipulated that "every person residing in the West Bank prior to 31.7.1988 is a Palestinian and not a Jordanian citizen."134 Although some commentators have questioned whether the divestiture of West Bank Palestinians of their Jordanian citizenship was valid under Jordanian domestic law, ${ }^{135}$ such validity was recognized by the High Court of Justice in Jordan, which considered the

129 Yousef T. Jabareen, The Politics of Equality: The Limits of Collective Rights Litigation and the Case of the Palestinian-Arab Minority in Israel, 4 COLUM. J. RACE \& L. 23, 30 n. 28 (2013) ("The majority of Palestinians in the West Bank and Gaza hold no citizenship in any country .... The vast majority of Palestinians in the occupied Palestinian territories are stateless ....").

130 Lewis Saideman, Do Palestinian Refugees Have a Right of Return to Israel? An Examination of the Scope of and Limitations on the Right of Return, 44 VA. J. INT'L L. 829, 868-69 (2004); BENVENISTI, supra note 26, at 204.

131 BENVENISTI, supra note 26, at 204 (observing with regard to the annexation by Jordan of the West Bank, "[t]his purported annexation ... was, however, widely regarded, including by the Arab League, as illegal and void, and was recognized only by Britain, Iraq, and Pakistan").

132 Law No. 6 of 1954 on Nationality, art. 3(2) (Jordan), Al-Jaridah alRasmiyyah lil-Mamlakah al-Urduniyyah al-Hasimiyyah, No. 1171, https://www.refworld.org/docid/3ae6b4ea13.html [https://perma.cc/H5694VYJ]; Saideman, supra note 130, at 869.

133 John Quigley, The Israel-PLO Interim Agreements: Are they Treaties?, 30 CORNELl INT'L L.J. 717, 728 (1997); Al Kour v. Minister of Interior, Jordanian High Court of Justice, 39 JORDANIAN BAR Ass'N, 1040 (1991), translated in 6 PALESTINE Y.B. INT'L L. 68 (1990-1991).

$134 \mathrm{Al}$ Kour, 6 PALESTINE Y.B. INT'L L. at 70 (citing the instructions issued by the Jordanian government).

135 E.g., Saideman, supra note 130, at 873-74. 
instructions issued by the government as "acts of the State acting as a sovereign." 136

The debate on whether or not a Palestinian state exists and holds title to the territory of the West Bank ${ }^{137}$ does not seem to bear on the status of the Palestinians as stateless, as far as IHRL is concerned. To the extent that a Palestinian state exists, the citizenship it extends to West Bank Palestinians is largely void of substance, because under Israeli occupation such a state has never had the capacity to offer Palestinians the benefits typically associated with citizenship. 138 The lack of effective Palestinian control over the West Bank is the main argument in support of the view that the Palestinian political entity in that area does not meet the test for statehood under international law. ${ }^{139}$ Assuming that international law would recognize the existence of a state that does not have, and has never had, the capacity to extend effective citizenship - a highly doubtful proposition-relying on such recognition to narrow the sphere of individuals who benefit from the human rights treaty provisions on the prevention of statelessness would undercut the rationale underlying these provisions.

\section{e. Summary}

The above analysis showed that a plausible, albeit not undisputed, reading of treaty provisions that are binding on Israel

136 Al Kour, 6 PALESTINE Y.B. INT'L L.at 70.

137 See, e.g., JaMES CRAWFord, THE CREATION Of STATES In INTERNATIONAL LAW 446-47 (2nd ed. 2006) (rejecting the contention that a Palestinian state already exists); Paul Eden, Palestinian Statehood: Trapped Between Rhetoric and Realpolitik, 62 INT'L. COMPAR. L.Q. 225, 233 (2013) (“[T]he powers currently possessed by the Palestinian Authority fall short of the independence necessary for Palestine (as currently constituted) to be regarded as a sovereign State."); John Quigley, Palestine is a State: A Horse with Black and White Stripes is a Zebra, 32 MicH. J. INT'L L. 749, 752 (2011) (contending that Palestine is a state); Francis A. Boyle, The Creation of the State of Palestine, 1 EUR. J. INT'L L. 301, 301-03 (1990) (arguing that Palestine meets the criteria for statehood).

138 Jabareen, supra note 129 (" $[$ W]ith the new recognition by 138 states of Palestine as a state, Palestinians in the West Bank, Gaza, and East Jerusalem may find themselves eligible for passports and nationality in the state of Palestine. It is questionable, however, what kind of citizenship rights the state of Palestine could provide as long as it remains under Israeli occupation.").

139 Eden, supra note 137, at 233-34. 
in matters of nationality, namely, Article 24(3) of the ICCPR and Article 7 of the Child Convention, suggests that Israel is obligated to grant citizenship to individuals born in its territory, who would otherwise be stateless. This part further argued that most West Bank Palestinians are currently considered stateless. Therefore, if a given area of the West Bank is considered to have become part of Israel, most Palestinians subsequently born in such territory are plausibly entitled to receive Israeli citizenship under the treaty obligations of Israel, as a party to the ICCPR and to the Child Convention.

In the case of lawful annexation of territory by a state as a form of state succession, there also seems to be an emerging right under customary international law of the residents of the annexed territory to receive the citizenship of the annexing state. The ILC Draft Articles and the legal literature suggest that this emerging right, yet to consolidate as lex lata, would not be restricted to children and would not depend on whether or not the individuals concerned are otherwise stateless.

International law prohibits the unilateral annexation by Israel of the occupied West Bank. The inquiry regarding the right of West Bank Palestinians to Israeli citizenship must therefore answer two questions. First, do the treaty obligations of Israel in matters of nationality, and the broader, emerging right to nationality under customary international law, extend to the residents of territory that has been illegally annexed by Israel? In other words, would the illegal annexation by Israel of the West Bank make that territory $a$ part of Israel for the purposes of applying the norms of IHRL that concern the right to nationality? Second, if the answer to the first question is affirmative, do the policies pursued by Israel in relation to the occupied West Bank amount to annexation?

\section{ILLEGAL ANNEXATION AND THE RIGHT TO CITIZENSHIP}

\section{a. Illegal Annexation and the Obligation of Non-Recognition}

Attaching to illegal annexation a legal effect that extends as far as the emergence of citizenship rights stands in tension with a wellestablished norm of customary international law, which holds that 
such annexation is null and void. ${ }^{140}$ As noted by Yoram Dinstein, "any unilateral annexation by the Occupying Power of an occupied territory - in whole or in part-would be legally stillborn."141 This norm derives from a fundamental principle of international law concerning the inadmissibility of the acquisition of territory through the use of force. ${ }^{142}$

Moreover, the annexation by an occupier of an occupied territory violates the right of peoples to self-determination, ${ }^{143}$ and possibly the prohibition against the use of force. ${ }^{144}$ Both the right to self-determination and the prohibition against the use of force have acquired the status of peremptory norms of customary international law. ${ }^{145}$ These norms are reinforced by the international law on the

140 See S.C. Res. 478, 9 2-3 (Aug. 20, 1980) (unanimously decreeing that the annexation by Israel of occupied East Jerusalem is a violation of international law and is therefore "null and void"); AeyAl Gross, The Writing ON THE WALL: RETHINKING THE INTERNATIONAL LAW OF OCCUPATION 24 (2017) ("Annexation . . . does not alter the status of the territory or its population.").

141 DinSTEIN, supra note 15 , at 50.

142 See S.C. Res. 242, pmbl. (Nov. 22, 1967) (emphasizing "the inadmissibility of the acquisition of territory by war"); Legal Consequences of the Construction of a Wall in the Occupied Palestinian Territory, Advisory Opinion, 2004 I.C.J. 136, 9 117 (July 9) (citing resolutions adopted by the U.N. General Assembly and the U.N. Security Council, which "have referred, with regard to Palestine, to the customary rule of 'the inadmissibility of the acquisition of territory by war'"); BENVENISTI, supra note 26, at 6 ("The foundation upon which the entire law of occupation is based is the principle of inalienability of sovereignty through unilateral action of a foreign power, whether through the actual or the threatened use of force, or in any way unauthorized by the sovereign.").

143 Legal Consequences of the Construction of a Wall in the Occupied Palestinian Territory, Advisory Opinion, 2004 I.C.J. 136, \ 1 121-22 (July 9) (noting that actions by Israel that may result in the de facto annexation of parts of the West Bank violate the right of the Palestinian people to self-determination).

144 BENVENISTI, supra note 26, at 245, 349 (noting that de facto annexation of occupied territory amounts to aggression).

145 See Glen Anderson, A Post-Millennial Inquiry into the United Nations Law of Self-Determination: A Right to Unilateral Non-Colonial Secession?, 49 VAND. J. TRANSNAT'L L. 1183, 1185 (2016) ("[S]elf-determination is widely regarded as a peremptory norm (jus cogens) . . . ."); Peter G. Danchin, Suspect Symbols: Value Pluralism as a Theory of Religious Freedom in International Law, 33 YALE J. INT'L L. 1, 11 n.29 (2008) ("In the opinion of many jurists and writers, selfdetermination ... enjoys the status of a peremptory norm (jus cogens)."); Military and Paramilitary Activities in and Against Nicaragua (Nicar. v. U.S.), Judgment, 1986 I.C.J. 14, ๆ 190, 212 (June 27) (recognizing the prohibition on the use of force as a peremptory norm); DINSTEIN, supra note 28, at 99-104 (discussing the peremptory nature of the prohibition on the use of force). 
responsibility of states for internationally wrongful acts, which decrees that states are under an obligation not to recognize as lawful a situation created by a serious breach of a peremptory norm of general international law, nor render aid or assistance in maintaining that situation ${ }^{146}$ ("obligation of non-recognition"). The obligation of non-recognition is a manifestation of the principle of legality in international law. As noted by one commentator:

[T] he rationale of the obligation of non-recognition is to prevent, in so far as possible, the validation of an unlawful situation by seeking to ensure that a fait accompli resulting from serious illegalities do not consolidate and crystallize over time into situations recognized by the international legal order .... [T] The function of non-recognition is to vindicate the "legal character of international law against the "law-creating effect of facts."' 147

The ILC observed that the obligation of non-recognition "not only refers to the formal recognition of [a situation created by a breach of a peremptory norm], but also prohibits acts which would imply such recognition." 148 This prohibition seems to extend to "'any action which might confer a semblance of legitimacy on the illegal regime.'"149

Recognizing a right to citizenship based on illegal annexation would not cure the unlawfulness of the annexation. The "legally stillborn" annexation would be brought to life only for the limited purpose of citizenship, and its status as legally void would otherwise remain unchanged. Yet, attaching to an illegal annexation

\footnotetext{
146 Int'1 Law Comm'n, Rep. on the Responsibility of States for Internationally Wrongful Acts on its Fifty-Third Session, U.N. Doc. A/56/10, at 114, art. 41(2) (2001) [hereinafter Draft Articles on Responsibility of States], http://legal.un.org/ilc/texts/instruments/english/commentaries/9_6_2001.pdf [https://perma.cc/8JJM-9QGB].

147 Martin Dawidowicz, The Obligation of Non-Recognition of an Unlawful Situation, in THE LAW OF INTERNATIONAL RESPONSIBILITY 677, 678 (James Crawford, Alain Pellet \& Simon Olleson eds., 2010) (quoting HERSCH LAUTERPACHT, RECOGNITION IN INTERNATIONAL LAW 430 (1947)).

148 Draft Articles on Responsibility of States, supra note 146, at 114, cmt. 5 (alteration in original).

149 Dawidowicz, supra note 147, at 680 (quoting G.A. Res. 2946 (XXVII) (Dec 7, 1972). See also G.A. Res. 2946 (XXVII), I 5 (Dec. 7, 1972).
} 
legal consequences that extend as far as citizenship, the distinguishing mark of the relationship between individuals and their state, would strengthen the political claim of the annexing state to sovereignty over the annexed territory, and would thereby erode the political force of the principle of the inadmissibility of the acquisition of territory through the use of force. Attributing such legal effect to illegal annexation implicitly indicates a degree of recognition by international law of the validity of the illegal annexation, and cannot be reconciled with an absolute norm mandating that such annexation is null and void. This departure from the obligation of non-recognition would exact a toll on the principle of legality in international law.

Yet, international law has allowed for limited erosion of the principle that an illegal annexation is null and void, and of its corollary, the obligation of non-recognition. The interests underlying these norms must, at times, be balanced against human rights, and the contours of this balancing have been delineated by international jurisprudence. The ICJ noted, in the 1971 Namibia Advisory Opinion, 150 the obligation of states not to recognize the authority of the illegal regime maintained by South Africa in Namibia. ${ }^{151}$ The ICJ recognized, however, an exception to the obligation of non-recognition (the "Namibia exception"), which considers the interests of individuals residing in territory controlled by the illegal regime. The ICJ stated:

In general, the non-recognition of South Africa's administration of the Territory should not result in depriving the people of Namibia of any advantages derived from international co-operation. In particular, while official acts performed by the Government of South Africa on behalf of or concerning Namibia ... are illegal and invalid, this invalidity cannot be extended to those acts, such as, for instance, the registration of births, deaths and marriages, the

150 Legal Consequences for States of the Continued Presence of South Africa in Namibia (South West Africa) Notwithstanding Security Council Resolution 276 (1970), Advisory Opinion, 1971 I.C.J. I 16 (June 21).

151 Id. ๆ 123-24 (June 21). 
effects of which can be ignored only to the detriment of the inhabitants of the Territory. ${ }^{152}$

Delineating the scope of the exception to the obligation of nonrecognition, the majority opinion in the Namibia Advisory Opinion referred only to ex post facto recognition of acts of routine administration, such as the registration of births, marriages, and deaths. Yet, "the increasingly voluminous body of human rights law has had an important effect on the obligation of non-recognition and on the exception to it."153 Thus, in recent years, the European Court of Human Rights ("ECtHR") has adopted a broad construction of the Namibia exception, which provides for a broad ex ante recognition of the legal authority of an illegal regime to the extent that such authority is necessary for compliance with the positive obligations of the regime to ensure and protect human rights. This court examined the legislative and adjudicative authority of the "Turkish Republic of Northern Cyprus" ("TRNC"), an entity proclaimed as a state by the Turkish-Cypriot community in the territory of northern Cyprus following the Turkish occupation of that territory. 154

The proclamation of the TRNC was widely condemned by the international community as a violation by Turkey of international law. ${ }^{155}$ No state except Turkey recognized the TRNC as a state, and northern Cyprus remained in the eyes of the international community a territory under Turkish occupation. ${ }^{156}$ The ECtHR has recognized, however, the validity of criminal laws enacted by the illegal regime of the TRNC on the ground that criminal legislation is an essential instrument for the protection of human rights, and its invalidity would be detrimental to the local population. ${ }^{157}$ Similarly, the ECtHR recognized the validity of TRNC legislation that provides

\footnotetext{
$152 \quad$ Id. $\ 125$.

153 YaËL Ronen, Transition From IlLEGal Regimes Under InTERnAtional LAW 88 (2011).

154 See Rhodri C. Williams, Introductory Note to the European Court of Human Rights: Demopoulos v. Turkey, 49 INT'L LEgAL MATERIALs 816, 816-17 (2010), for a historical review of the Turkish invasion and occupation of northern Cyprus and the establishment of the "Turkish Republic of Northern Cyprus" [TRNC].

155 Loizidou v. Turkey, 1996-VI Eur. Ct. H.R. 513, ๆ 1 19-23.

156 Williams, supra note 154 , at 816.

157 Foka v. Turkey, App. No. 28940/95, Eur. Ct. H.R. ๆ 83 (2008); Protopapa v. Turkey, App. No. 16084/90, Eur. Ct. H.R. ๆ 60 (2009).
} 
remedies for human rights violations, as well as the authority of TRNC courts to apply this legislation,158 citing the need to "avoid in the territory of northern Cyprus the existence of a vacuum in the protection of ... human rights." 159 Citing a threshold condition for the admissibility of applications to the ECtHR, which requires applicants to exhaust domestic remedies before applying to the Court, the ECtHR held that victims of human rights violations by Turkey in northern Cyprus cannot apply to the ECtHR before exhausting the remedies offered by the TRNC legal system. ${ }^{160}$ It was thus observed that "the ECtHR's interpretation of the Namibia Exception calls for a broad ex ante recognition of the legislative and adjudicative authority of an illegal regime. This approach expands the scope of the Namibia Exception."161

The Court emphasized that this approach did not undermine the position taken by the international community regarding the illegality of the TRNC regime, and that it recognized the authority of TRNC institutions only "for the limited purpose of protecting the rights of the territory's inhabitants." 162 There is little doubt, however, that the broad recognition by the ECtHR of the legal authority of the TRNC "benefits the purported sovereignty of the illegal regime," 163 and significantly erodes the principle of nonrecognition. ${ }^{164}$ It has been noted that " $[t]$ his jurisprudence provides such a wide exceptional validity under the Namibia exception, that little remains of the obligation of non-recognition insofar as internal

158 See Cyprus v. Turkey, App. No. 25781/94, Eur. Ct. H.R. ๆ 9 91-98 (2001); Demopoulos v. Turkey, App Nos. 46113/99, 3843/02, 13751/02, 13466/03, 10200/04, 14163/04, 19993/04, 21819/04, Eur. Ct. H.R. ๆ 92-96 (2010).

159 Cyprus v. Turkey, App. No. 25781/94, Eur. Ct. H.R. q 91, 96 (2001); Demopoulos v. Turkey, App Nos. 46113/99, 3843/02, 13751/02, 13466/03, 10200/04, 14163/04, 19993/04, 21819/04, Eur. Ct. H.R. ๆ 9 92-96 (2010).

160 Cyprus v. Turkey, App. No. 25781/94, Eur. Ct. H.R. बף 98-99 (2001); Demopoulos v. Turkey, App Nos. 46113/99, 3843/02, 13751/02, 13466/03, 10200/04, 14163/04, 19993/04, 21819/04, Eur. Ct. H.R. ๆ 9 96-98 (2010). (2017).

161 Michal Saliternik, Bad Reliance in Public Law, 68 HASTINGS L.J. 1243, 1285

162 Cyprus v. Turkey, App. No. 25781/94, Eur. Ct. H.R. ๆ 91-92 (2001); see also Foka v. Turkey, App. No. 28940/95, Eur. Ct. H.R. ๆ 84 (2008).

163 RoNEN, supra note 153, at 95.

164 Gross, supra note 140, at 93-94 ("Northern Cyprus is viewed as occupied territory and the TRNC is unrecognized and considered illegal. But this determination has been gradually eroded in the ECtHR's case law."'). 
acts are concerned." 165 This expansive construction of the Namibia exception is directly linked to the development of IHRL in the decades following the Namibia Advisory Opinion. 166

The breadth of the exception to the obligation of non-recognition in the jurisprudence of the ECtHR seems to support extending the norms of IHRL on the right to citizenship to situations of illegal annexation. Both the annexation by an occupier of the occupied territory and the establishment of the TRNC by Turkey, the occupier of northern Cyprus, create an illegal regime in the occupied territory, contrary to peremptory norms of international law. ${ }^{167}$ The competing interests underlying the delineation by the ECtHR of the exception to the obligation of non-recognition are identical to the interests at stake when it comes to recognizing the legal effect of an illegal annexation for the purpose of the right to citizenship: the rights of the ousted sovereign, or in current parlance, the right to self-determination, and the principle of legality, on one hand, and the human rights of individuals, on the other. The breadth of the exception to the obligation of non-recognition in the jurisprudence of the ECtHR suggests that international law is inclined to grant the latter precedence over the former. This inclination arguably extends to the right of the residents of an unlawfully annexed territory to receive the citizenship of the annexing state.

The ILC has explicitly restricted the purview of its Draft Articles "to the effects of a succession of States occurring in conformity with international law and, in particular, with the principles of international law embodied in the Charter of the United Nations." 168 In the view of the ILC, "it was not incumbent upon it to study questions of nationality which could arise in situations such as illegal annexation of territory." 169 One commentator has noted that

165 RoNEN, supra note 153 , at 92.

166 Id. at 94 ("[T]he expansion of the Namibia exception is an inevitable consequence of the expansion of international human rights law, which was not fully envisaged in 1971.").

167 See Glen Anderson, Unilateral Non-Colonial Secession and the Criteria for Statehood in International Law, 41 BROOK. J. INT'L L. 1, 75 (2015) (noting that the TRNC was denied statehood because it was established in breach "of the interconnected peremptory norms of the right of peoples to self-determination and the prohibition on the illegal use of force").

168 ILC Draft Articles on Nationality, supra note 10, at 27, art. 3.

169 Id. at 27, art. 3, cmt. 2. 
in placing this restriction on the purview of its Draft Articles, "the ILC confirmed that different rules and considerations apply in situations of territorial changes contrary to international law," 170 so that in such situations " $\mathrm{t}]$ he starting point ... on whether there are any relevant rules affecting regulation of nationality is clearly different." 171 Note, however, that the ILC did not exclude the possibility of a citizenship right emanating from an illegal annexation. In its Commentary to the Draft Articles, the ILC stressed that the restriction of its Draft Articles to situations of lawful succession of states "is without prejudice to the right of everyone to a nationality in accordance with Article 15 of the Universal Declaration of Human Rights." 172

The difference between any unilateral annexation by Israel of the West Bank and situations of state succession addressed in the legal literature on the right to citizenship and in the ILC Draft Articles extends beyond the illegality of the former. A succession of states concerns the replacement of a predecessor state by a successor state in the sovereignty over territory. ${ }^{173}$ To the extent that Israel has annexed the West Bank, it is far from clear that there existed a predecessor state, namely, a sovereign state of Palestine. Yet the human rights rationale underlying the emerging right to citizenship in situations of state succession equally applies where a state annexes territory that was not a part of another state prior to the annexation. The ILC indicated that the right to nationality laid out in the Draft Articles "applies to this particular situation [of succession of states] the general principle contained in Article 15 of the Universal Declaration of Human Rights, which was the first international instrument embodying the "right of everyone to a nationality.'" 174 This general principle seems to support the extension of the emerging right to citizenship to situations of

170 Ziemele, supra note 99 , at 229.

171 Id. at 236.

172 ILC Draft Articles on Nationality, supra note 10, at 27, art. 3, cmt. 3.

173 Id. at 25, art. 2(a) ("'Succession of States' means the replacement of one State by another in the responsibility for the international relations of territory.").

174 Id. at 25, art. 1, cmt. 1 (alteration in original) (footnote omitted). 
annexation that do not fall squarely within the definition of state succession. ${ }^{175}$

In conclusion, this part has shown that the existing and emerging IHRL obligations of Israel to grant citizenship to residents of territory acquired by Israel extend to Palestinians residing in areas of the West Bank illegally annexed by Israel. In other words, an occupied territory unlawfully annexed by the occupier may be viewed as part of the occupier's own territory for the limited purpose of the right to citizenship.

\section{b. The Right of East Jerusalem Palestinians to Israeli Citizenship}

In contrast to the bulk of the occupied West Bank, East Jerusalem has been formally annexed by Israel. ${ }^{176}$ Therefore, even under a narrow perception of annexation limited to formal annexation, the existing and emerging IHRL obligations of Israel to grant citizenship to residents of territory acquired by Israel seem to apply to Palestinian residents of East Jerusalem.

The path to citizenship for East Jerusalem Palestinians formally laid out by domestic Israeli law seems consistent with the IHRL treaty obligations of Israel under the ICCPR and the Child Convention, regarding the granting of citizenship to persons born in

175 As a corollary of its narrow definition of succession of states, which requires the existence of both a predecessor state and a successor state, the ILC has limited the category of individuals whose right to citizenship is discussed in its Draft Articles to "every individual who, on the date of the succession of States, had the nationality of the predecessor State and whose nationality may be affected by such succession." See id. at 26, art. 2(f). This limitation seems irrelevant, however, to situations in which an annexed territory was not a part of any state prior to its annexation. It has been noted that the ILC has followed "the principle that aliens resident in the territory do not acquire the nationality of the successor state." See Blackman, supra note 52, at 1168. This principle would hardly be relevant to an Israeli annexation of the West Bank, as the Palestinian residents of the West Bank cannot be considered aliens in this territory.

176 See § 1, Basic Law: Jerusalem, Capital of Israel, 5740-1980, SH 980 186, (Isr.), https://www.knesset.gov.il/laws/special/eng/basic10_eng.htm [https:/ / perma.cc/ZHT8-AC39] ("Jerusalem, complete and united, is the capital of Israel."); HCJ 282/88 Awad v. Prime Minister, 42(2) PD 424, 429 (1988) (Isr.) (noting that Israel has annexed East Jerusalem); see also Asher Maoz, Application of Israeli Law to the Golan Heights is Annexation, 20 BROOK. J. INT'L L. 355, 366 (1994) (noting that the enactment by Israel of Basic Law: Jerusalem, Capital of Israel has consolidated the annexation of East Jerusalem). 
Israel who would otherwise remain stateless. The opportunity to acquire citizenship formally offered by Israel to the residents of East Jerusalem may conceivably be reconciled also with the broader, emerging norm of customary international law regarding the right of persons residing in territory acquired by a state to receive the citizenship of the latter.

The provisions of the Israeli Citizenship Law ${ }^{177}$ on the right of stateless persons born in Israel to receive Israeli citizenship follow the requirements of the Convention on the Reduction of Statelessness, 178 although Israel is not party to the Convention. Section $4 \mathrm{~A}$ of the Citizenship Law stipulates that:

A person born after the establishment of the State of Israel in a place that was an Israeli territory at the date of his birth, and has never possessed any citizenship, will become an Israeli citizen if he so requests within the period between his eighteenth birthday and his twenty-first birthday, provided that he has been a resident of Israel in the five consecutive years prior to the submission of the request ("Statelessness Clause"). .179

The Minister of Interior has no discretion to deny the request other than on the grounds that the person in question was convicted of a national security offense, or was sentenced to imprisonment of five years or more, having been convicted of any other offense. 180

Although many East Jerusalem Palestinians are eligible for citizenship under the Statelessness Clause, 181 the Israeli government has adopted a policy, yet to be reviewed by the courts, of channeling requests for citizenship by East Jerusalem Palestinians away from the Statelessness Clause, and processing such requests only under the general naturalization provision contained in Section 5 of the Citizenship Law, which is not limited to cases of statelessness. 182 (Isr.).

177 See generally Citizenship Law, 5712-1952, LSI 650 (1951-52), as amended

178 See Statelessness Convention, supra note 70, and accompanying text.

$179 \S 4$ A(a), Citizenship Law, 5712-1952, LSI 650 (1951-52), as amended (Isr.).

180 § 4A(b), Citizenship Law, 5712-1952, LSI 650 (1951-52), as amended (Isr.).

181 Amnon Ramon \& Yä̈l Ronen, Residents, Not Citizens: IsRaeli Policy TOWARDS THE ARABS IN EAST JERUSALEM, 1967-2017 at 311 (2017).

182 Id. at 311-12. 
Section 5 of the Citizenship Law offers a path to citizenship through naturalization to those who have been lawfully residing in Israel for three of the five years preceding the application for citizenship, provided that the applicant possesses some knowledge of the Hebrew language and has renounced or otherwise forfeited foreign citizenship. 183 Although Section 5 provides that the granting of citizenship to individuals who meet these preconditions is subject to the discretion of the Minister of Interior, 184 the Supreme Court of Israel appears to have taken the position that East Jerusalem Palestinians who meet these preconditions are generally entitled to citizenship. 185 The Court noted that the entire population of East Jerusalem would have been granted Israeli citizenship in the wake of the Israeli annexation of East Jerusalem in 1967, were it not for the Palestinians' own rejection of Israeli citizenship, and that "each one [of the residents of East Jerusalem] has been given the option to apply [individually] and receive Israeli citizenship .... Some have applied and received Israeli citizenship." 186

Israel has placed procedural hurdles in the path to citizenship offered to East Jerusalem Palestinians. The most significant of those has been an unreasonably long timeframe of around six years for receiving and processing citizenship applications. ${ }^{187}$ In some cases, Israel has also presented applicants for citizenship with unrealistic evidentiary requirements to prove residency in East Jerusalem. ${ }^{188}$ These procedural hurdles can hardly be reconciled with an entitlement of East Jerusalem Palestinians to citizenship, and may

183 § 5(a) Citizenship Law, 5712-1952, LSI 650 (1951-52), as amended (Isr.).

184 § 5(b) Citizenship Law, 5712-1952, LSI 650 (1951-52), as amended (Isr.).

185 AdminA (DC Jer) 5829/05 Dari v. Ministry of the Interior, 99 Nevo Legal Database (Feb. 1, 2007) (Isr.). Under the procedure laid out by the Ministry of the Interior, citizenship applications may be rejected on security grounds or if the applicant has been otherwise involved in criminal activity according to information provided to the Minister by Israeli police. See RAMON \& RONEN, supra note 181, at 313. These grounds for rejecting citizenship applications are yet to be reviewed by the courts.

186 AdminA (DC Jer) 5829/05 Dari v. Ministry of the Interior, 99 Nevo Legal Database (Feb. 1, 2007) (Isr.) (alteration in original).

187 Nir Hasson, Israel Vows to Drastically Cut Wait Time for Jerusalem Palestinians' Citizenship Applications, HAARETZ (Feb. 26, 2019), https://www.haaretz.com/israel-news/.premium-israel-vows-to-cut-wait-timefor-jerusalem-palestinians-citizenship-applications-1.6975728 [https:/ / perma.cc/N4LM-4KAU].

188 RAMON \& RONEN, supra note 181, at 312. 
be viewed as contrary to existing and emerging IHRL norms on the right to citizenship applicable to Israel. The Israeli government, however, has recently pledged to the Supreme Court to drastically expedite the naturalization process for East Jerusalem Palestinians, so that the overall waiting period for submission and processing of citizenship applications would be reduced to one year. ${ }^{189}$

In the five decades that have passed since the annexation of East Jerusalem, only a small minority of East Jerusalem Palestinians have applied for Israeli citizenship. ${ }^{190}$ The reluctance of East Jerusalem Palestinians to apply for Israeli citizenship is largely of a political nature because such action is perceived as a form of recognition of Israeli sovereignty over East Jerusalem, contrary to Palestinian national aspirations to establish a Palestinian state with East Jerusalem as its capital. ${ }^{191}$ In the past decade, however, as the possibility of establishing a viable Palestinian state that extends to East Jerusalem has become more and more distant, there has been a sharp increase in the number of East Jerusalem Palestinians applying for Israeli citizenship. ${ }^{192}$ Commentators predict that the expected shortening of waiting periods for the receipt of citizenship will further increase the number of citizenship applications submitted by East Jerusalem Palestinians. ${ }^{193}$

189 Hasson, supra note 187; see also Nir Hasson, Israel Picks Up Pace, Grants Citizenship to 1,200 East Jerusalem Palestinians, HAARETZ (Jan. 12, 2020), https:/ / www.haaretz.com/israel-news/.premium-israel-picks-up-pace-grantscitizenship-to-1-200-east-jerusalem-palestinians-1.8384270

[https:/ / perma.cc/BW3G-DTE9] (noting that recent data indicates that, in 2019, the government has expedited the processing of citizenship applications submitted by residents of East Jerusalem).

190 Michael Bachner, Israel to Dramatically Shorten East Jerusalemites' Path to Citizenship - Report, TIMES IsR. (Feb. 27, 2019, 1:46 AM), https://www.timesofisrael.com/israel-to-dramatically-shorten-eastjerusalemites-path-to-citizenship-report/ [https:/ / perma.cc/5ZYW-64TP].

191 Yaffa Zilbershats, Apartheid, International Law, and the Occupied Palestinian Territory: A Reply to John Dugard and John Reynolds, 24 EUR. J. INT'L L. 915, 918 (2013) (Following the annexation by Israel of East Jerusalem, the Palestinian residents of the territory "were given the option of receiving Israeli citizenship, but at the time, for political reasons, most chose not to request it.").

192 RAMON \& RONEN, supra note 181 , at 316.

193 Hasson, supra note 187. 


\section{WHAT AMOUNTS TO ANNEXATION?}

It has been observed that "international law today has more to say about the legal consequences of an annexation than about what qualifies as one." 194 The international community has taken the view that the full extension by an occupying state of its legislative jurisdiction, judicial system, and administration to the occupied territory amounts to annexation, whether or not these measures are accompanied by an explicit proclamation of annexation by the occupier. ${ }^{195}$ Israel has taken legislative measures extending the application of Israeli "law, jurisdiction and administration" to East Jerusalem 196 and to the occupied Golan Heights. ${ }^{197}$ Israeli commentators and judges disagreed on whether these measures, which were not accompanied by an explicit proclamation of annexation, amounted to an act of annexation, 198 but the international community overwhelmingly considered these

194 Dajani, supra note 18, at 52.

195 See infra notes 196-199 and accompanying text.

196 Law and Administration Order (No. 1), 5727-1967 (June 28, 1967).

$197 \S 1$, Golan Heights Law, 5742-1981, LSI 367 (1981-82) (Isr.).

198 See, e.g., Maoz, supra note 176, at 356-57 (noting that Israeli legislation applying the laws, jurisdiction and administration of Israel to the Golan Heights amounts to the annexation of this territory); Leon Sheleff, The Application of Israeli Law to the Golan Heights is Not Annexation, 20 BROOK. J. INT'L L. 333, 337 (1994) (arguing that the Israeli legislation concerning the Golan Heights "does not amount to annexation because it does no more than what is written therein; apply Israeli law, administration and government to the Golan Heights"); HCJ 283/69 Ruweidi v. Military Court in the Hebron District, 24(2) PD 419, 423 (1970) (Isr.) (examining whether East Jerusalem is considered a part of Israel under domestic Israeli law, Justice Cohn noted that "the thesis . . . that the application of Israeli law to a particular area, is equivalent to the annexation of the area to the State of Israel, still requires proof," and that "there is ... nothing to prevent the application of the law of Israel to occupied territories even in the absence of any intention to annex them to the area of the state"); Id. at 424 (Justice Yitzhak Kahan) ("[East Jerusalem] was annexed to the State of Israel and constitutes part of its area."). The controversy on whether Israel annexed East Jerusalem has been resolved with the enactment by the Israeli legislature of Basic Law: Jerusalem, Capital of Israel, which stipulated that "Jerusalem, complete and united, is the capital of Israel." See Maoz, supra note 176, at 366 (noting that following the enactment of the Basic Law, "there can no longer be any argument regarding ... Jerusalem's constituting 'part of the territory of the state of Israel.'"); Sheleff, supra note 198, at 344. 
measures as such. ${ }^{199}$ I refer to the full extension by the occupier of its legislative jurisdiction, judicial system, and administration to the occupied territory as "formal annexation." 200

International law is unclear, however, on whether and to what extent annexation of occupied territory may arise from conduct on the part of the occupier that does not amount to formal annexation. ${ }^{201}$ With the exception of East Jerusalem, Israel has not effected the formal annexation of the West Bank. Plans to formally annex large parts of the West Bank, recently announced by the Prime Minister of Israel, 202 are yet to materialize. Israeli efforts to integrate parts of the West Bank into Israel in the absence of formal annexation, manifest in the settlement enterprise, have typically targeted only territories outside Palestinian population centers, ${ }^{203}$ as do plans to formally annex parts of the West Bank. ${ }^{204}$

\footnotetext{
199 See G.A. Res. 52/68, q 7 (Feb. 20, 1998), https://undocs.org/en/A/RES/52/68 [https://perma.cc/HU4L-H77D] ("Reaffirming once more the illegality of the decision of 14 December 1981 taken by Israel to impose its laws, jurisdiction and administration on the occupied Syrian Golan, which has resulted in the effective annexation of that territory."); G.A. Res. 51/135, I 7 (Mar. 24, 1997), https://undocs.org/en/A/RES/51/135 [https://perma.cc/7AKP-VGWE]; Statement by the Foreign Ministers of the European Community, Statement by the Foreign Ministers of the Ten on Poland and Israeli Golan Heights Policy (Dec. 15, 1981), http://aei.pitt.edu/5583/1/5583.pdf [https://perma.cc/EGF8-VL6B] (maintaining that the extension of Israeli law, jurisdiction and administration to the Golan Heights is "tantamount to annexation"); Maoz, supra note 176, 384-89 (reviewing the response of the international community to the application of Israeli law, jurisdiction and administration to the Golan Heights, which regarded this measure as annexation); BENVENISTI, supra note 26, at 205 (noting that the international community understood the application by Israel of its laws, jurisdiction and administration to East Jerusalem as an attempt to annex East Jerusalem).

200 The discussion below suggests that a proclamation of annexation that remains an empty shell, namely, one that is not accompanied by the occupier's application of its legal and administrative systems to the occupied territory or by any other operative measures by which the occupier treats the occupied territory as its own, does not amount to annexation for the purpose of the right to citizenship. See Part IV.c, infra.

201 See Kleinfeld, supra note 18, at 2495, 2498; Dajani, supra note 18, at 52; see also supra text accompanying notes 18-19.

202 See supra notes 1-3 and accompanying text.

203 See supra note 5 and accompanying text.

204 See Holmes, supra note 2, and accompanying text.
} 
This Part explores two questions. First, should portions of the West Bank be viewed, for the purpose of recognizing the right of Palestinian residents of these territories to Israeli citizenship, as part of Israel based on a doctrine that extends the concept of annexation beyond formal annexation to encompass de facto annexation as well? This Part answers this question in the affirmative and advances the display of sovereignty test for the existence of annexation, which brings together formal annexation and de facto annexation. This test for annexation is satisfied by the occupier's treatment of the occupied territory as its own, namely, the occupier's continuous exercise in the occupied territory of governmental functions that are typically reserved to a sovereign. The most distinct form of such display of sovereignty concerns the full extension by the occupier of its legal and administrative systems to the occupied territory. Yet, the occupier's treatment of the occupied territory as its own, which satisfies the display of sovereignty test for annexation, may also take the form of the settlement by the occupier of its own population within the occupied territory, large-scale infrastructure projects aimed at supporting such settlement activity, and a partial extension of the occupier's own legal system to the occupied territory.

Second, may the scope of annexation extend to population centers within the occupied territory that are not targeted by the occupier's displays of sovereignty, when the occupier aims to tailor its annexation of occupied territory around, and to the exclusion of, such population centers to advance a "maximum land, minimum population" annexation formula? This Part shows that a reasonable application of the display of sovereignty test for annexation, informed by the principle of legality in international law and by the right of the people under occupation to self-determination, supports recognizing such areas as annexed territory. This inquiry begins with a brief review of Israeli policies promoting the integration of parts of the West Bank into Israel. 


\section{a. The Integration of Occupied Territory into Israel}

\section{i. Facts on the Ground}

Commentators correctly observed that " $[t]$ he story of the [Israeli] occupation is inseparable from the settlement enterprise." 205 Therefore, a review of the factual and legal realities established by the settlement enterprise is essential for "identifying the basic structure and nature of this occupation regime." 206 The establishment of settlements by Israel in the West Bank began shortly after this territory came under Israeli occupation. At present, some 620,000 Israeli settlers reside in settlements and "settlement outposts" throughout the occupied West Bank.207 About 210,000 of the settlers reside in neighborhoods built by Israel in the expanded area of East Jerusalem, and some 410,000 settlers live in 131 settlements and roughly 110 settlement outposts in other parts of the West Bank. ${ }^{208}$

The ICJ has observed that the establishment of settlements violates Article 49 of the Geneva Convention Relative to the Protection of Civilian Persons in Time of War ("Fourth Geneva Convention"), which states that "[t]he Occupying Power shall not deport or transfer parts of its own civilian population into the territory it occupies." 209 The Court reasoned that the prohibition contained in Article 49 encompasses "not only deportations or forced transfers of population ... but also any measures taken by an occupying Power in order to organize or encourage transfers of parts of its own population into the occupied territory." 210 Similarly,

205 Ben-Naftali, Gross \& Michaeli, supra note 7, at 579.

206 Id.

207 Statistics on Settlements and Settler Population, B'Tselem (Jan. 16, 2019), https://www.btselem.org/settlements/statistics [https://perma.cc/3FBAWM7A].

208 Id.

209 Geneva Convention Relative to the Protection of Civilian Persons in Time of War art. 49, Aug. 12, 1949, 6 U.S.T. 3316, 75 U.N.T.S 287 [hereinafter Fourth Geneva Convention]; Legal Consequences of the Construction of a Wall in the Occupied Palestinian Territory, Advisory Opinion, 2004 I.C.J. 136, ๆ 120 (July 9).

210 Legal Consequences of the Construction of a Wall in the Occupied Palestinian Territory, Advisory Opinion, 2004 I.C.J. 136, 1120 (July 9). 
the U.N. Security Council has described Israel's settlement policy as a "flagrant violation of the Fourth Geneva Convention." 211 The settlements enterprise has been criticized as an annexationist measure. ${ }^{212}$

The settlements are supported by two main infrastructure projects cementing their connection to Israel. The first is a massive network of roads connecting the Israeli settlements to each other and to Israel, bypassing Palestinian cities and towns, and thereby "bringing Israeli territorial contiguity to the West Bank for the first time in modern history." 213 Because the bypass roads network is closed to Palestinians, it separates Palestinian population centers, ${ }^{214}$ dividing the West Bank into numerous non-contiguous zones. ${ }^{215}$ Elaborating on the adverse effects of the bypass roads on the national aspirations of the Palestinians, Samira Shah observed:

The bypass road network has devastating effects on Palestinian statehood, sovereignty, and self-determination. The roads carve up the West Bank, creating enclaves of Palestinian authority with definite boundaries. The roads prevent the expansion of these enclaves and ensure that there will be no territorial contiguity in the West Bank. To this end, there is a network of roads encircling every major Palestinian city. ${ }^{216}$

The settlement enterprise is also supported by a barrier constructed by Israel within the West Bank ("Barrier"). ${ }^{217}$ The

211 S.C. Res. 465, 15 (Mar. 1, 1980).

212 See Charles F. Martel, Give Peace a Chance: How Considering Peace Process Obligations Would Have Improved the Rulings of the International Court of Justice and the Israeli Supreme Court on the Israeli Security Barrier, 17 DUKE J. COMP. \& INT'L L. 305, 335 (2007) (noting that the settlement enterprise is intended to ensure lasting Israeli possession of the West Bank).

213 Samira Shah, On the Road to Apartheid: The Bypass Road Network in the West Bank, 29 Colum. HuM. RTs. L. REV. 221, 264-65 (1997).

214 Id. at 223 (observing that the bypass road network serves as "a military grid in the West Bank, dividing and surrounding the Palestinian regions with militarilycontrolled roads").

215 GROSs, supra note 140, at 154 (observing that the settlements and the bypass roads "have divided the West Bank into some sixty non-contiguous zones").

216 Shah, supra note 213, at 224-25.

217 Legal Consequences of the Construction of a Wall in the Occupied Palestinian Territory, Advisory Opinion, 2004 I.C.J. 136, ๆ $79-84$ (July 9). 
Barrier separates the bulk of the West Bank from both Israel proper and from portions of the West Bank located between the Barrier and the Green Line, which is the line that separates Israel proper from the West Bank. ${ }^{218}$ The construction of the Barrier by Israel began in 2002, following a wave of terror attacks committed against Israelis by Palestinians infiltrating Israel from the West Bank. The Barrier was justified by Israel as a security measure aimed at preventing terrorists from entering Israel and Israeli settlements in the West Bank that are located in proximity to the Green Line. ${ }^{219}$ The portions of the West Bank located on the Israeli side of the Barrier, between the Barrier and the Green Line, are home to most of the Israeli settlers as well as to Palestinian communities. ${ }^{220}$ The Barrier often cuts off access by Palestinians on both sides of the Barrier to their farmlands. ${ }^{221}$ It also isolates the Palestinians on the Israeli side of the Barrier from the bulk of the West Bank, significantly restricting their freedom of movement for purposes of work, trade, enjoyment of basic services (e.g., education, healthcare), visiting family and friends, and recreation. ${ }^{222}$

In its Advisory Opinion on the Legal Consequences of the Construction of a Wall in the Occupied Palestinian Territory ("Wall Advisory Opinion"), the ICJ concluded that the construction of the Barrier violates a range of humanitarian protections and human rights guaranteed to the Palestinian population of the West Bank under international humanitarian law and international human rights law.223 Noting that the area between the Barrier and the Green Line would include most Israeli settlements in the West Bank, and that the construction of the Barrier would likely contribute to the departure of Palestinians from this area, thereby altering its demographic composition, 224 the Court also expressed concern that the Barrier would facilitate the de facto integration of this area into Israel. ${ }^{225}$ Commentators have observed that "[t]he settlement

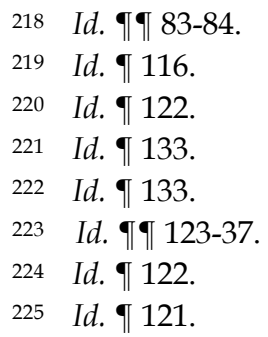


program and the barrier preserving it constitute a deliberately comprehensive physical, institutional, and demographic change in the status of the West Bank intended to create a political reality too difficult to reverse: lasting Israeli possession of contested territory." 226

\section{ii. $\quad$ The Legal System}

The facts on the ground established by the settlement enterprise walk hand in hand with the partial application of the Israeli legal system to the occupied West Bank. Aeyal Gross observed:

Two separate legal systems operate concurrently in the West Bank, effectively dividing the population along ethnic lines. Jewish settlers are extraterritorially subject to Israeli civilian law, whereas the Palestinians are subject to Israeli military law and to the local law. Two main methods were used to generate this situation. The first is the application of Israeli law in personam to Jews and Israeli citizens in the OPT [occupied Palestinian territories], and the second is the partial application of Israeli law, on a supposedly territorial basis, to the Jewish settlements in the OPT.227

The personal application of Israeli law to Israeli settlers in the West Bank is secured primarily by Israeli legislation that, for the purpose of Israeli statutes applicable to residents of Israel, extends the category of Israeli residents to Israeli citizens living in the West Bank. ${ }^{228}$ This legislation brings Israeli settlers in the West Bank within the purview of a wide range of Israeli statutes, including the Income Tax Ordinance, the Social Security Law, and the National Health Care Law. ${ }^{229}$ In addition, Israeli legislation extends the jurisdiction of Israeli courts to criminal offences committed by Israeli

226 Martel, supra note 212, at 335.

227 Gross, supra note 140, at 172; see also, Ass'N FOR Civ. RTS. IN IsR., ONE RULE, TwO LEGAL SYSTEMS: ISRAEL's REGIME OF LAWS IN THE WEST BANK 6 (2014) [hereinafter ASS'N FOR CIV. RTS. IN ISR.], https://law.acri.org.il/en/wpcontent/uploads/2015/02/Two-Systems-of-Law-English-FINAL.pdf [https://perma.cc/4E3T-PCDY].

228 GROSS, supra note 140 , at $172-73$.

229 Id. at 173. 
citizens in the West Bank.230 It was observed that " $\mathrm{t}$ ] he net result is a different set of rights and duties applying to different groups in the OPT, along ethnic lines." 231

The Israeli Parliament (the Knesset) has generally avoided extending its legislative jurisdiction to the West Bank on a territorial basis. ${ }^{232}$ The territorial application of Israeli law to the Israeli settlements is secured by military legislation enacted by the Military Commander of the West Bank. Although the Military Commander is an Israeli official, he is considered under international law to be the governmental authority of the occupied territory, formally distinct from the Israeli government. ${ }^{233}$ The Military Commander holds both legislative and administrative powers over the occupied

$230 \quad$ Id. at $172-73$.

231 Id. at 173

232 In 2017, the Israeli Knesset enacted the Law for the Regularization of Settlement in Judea and Samaria, which represented a direct extension by the Knesset of its legislative jurisdiction to the West Bank on a territorial basis. See Law for the Regularization of Settlement in Judea and Samaria, 5777-2017, SH 2064507 (Isr.) [hereinafter Regularization Law]. This legislation addressed many cases in which Israeli settlements had been established on privately owned Palestinian land. The legislation instructed the Military Commander in the West Bank to appropriate such land for the purpose of its continued use by Israeli settlers, provided that the settlement in question had been established "in good faith" or with the consent of the State. See id. art. 3. It has been noted that the Regularization Law "is a unique case of Knesset legislation that aims to directly regulate property rights over land outside of Israel's jurisdiction." See Elena Chachko, Israel's Settlement Regularization Law: the Attorney General's Extraordinary Brief and What it Means for Israel's Legal Stance on Illegal Settlements, LAWFARE (Dec. 8, 2017, 6:58 AM), https:/ / www.lawfareblog.com/israels-settlement-regularization-law-attorney-ge nerals-extraordinary-brief-and-what-it-means [https://perma.cc/UXQ4-TUA2]. The Regularization Law has been annulled by the Supreme Court of Israel, on the grounds that it amounted to an unconstitutional violation of the rights of Palestinian land owners to dignity, equality, and property, protected under the Israeli Basic Law: Human Dignity and Liberty. See HCJ 1308/17 Silwad Municipality v. the Knesset (2020) (Isr.); Tamar Hostovsky Brandes, The Diminishing Status of International Law in the Decisions of the Israeli Supreme Court Concerning the Occupied Territories, INT'L J. CONST. L. (forthcoming 2020) (on file with author) ("The Court circumvented the question of the application of the [Israeli] Basic Laws in the Occupied Territories by determining that the Knesset's authority to legislate is restricted by the Basic Laws, regardless of where a law is to take effect ....").

233 BENVENISTI, supra note 26, at 4 (The law of occupation requires that the administration established by the occupier in the occupied territory maintains "formal independence of the occupying state."). 
territory, which derive from the international law of occupation rather than from Israeli law. ${ }^{234}$

Immediately after the West Bank came under Israeli occupation, the Military Commander decreed, in accordance with the international law of occupation, that the laws existing in the West Bank prior to the occupation would remain in effect, subject to legislation promulgated by the Military Commander. ${ }^{235}$ This legal regime of pre-occupation law and military legislation ostensibly applies to the entire territory of the West Bank, including Israeli settlements. A series of by-laws promulgated by the Military Commander, however, apply Israeli laws concerning the operation of municipalities and the provision of governmental services within Israel to the Israeli settlements in the West Bank. ${ }^{236}$ These by-laws also established Courts of Domestic Affairs, a system of courts that serves only the settlements. 237 These courts are ostensibly separate from the judicial system of Israel, but follow the procedures prevailing in Israeli courts. ${ }^{238}$ The judges of the Courts of Domestic Affairs are appointed by the Military Commander from among the judges of Israeli courts.239 The military legislation establishing the

234 Uri Shoham, The Principle of Legality and the Israeli Military Government in the Territories, 153 MiL. L. REV. 245, 251 (1996) (“Under customary international law, the Military Commander of the occupying forces holds not only the highest executive power in the area but also the power to legislate."); HCJ 7957/04 Mara'abe v. Prime Minister of Israel, 60(2) PD 477, 492 (2005) (Isr.) (noting that the Military Commander derives his power from public international law pertaining to belligerent occupation).

235 BENVENISTI, supra note 26, at 212 (citing Proclamation Concerning Law and Administration (no. 2) (June 7, 1967), http://nolegalfrontiers.org/militaryorders $/$ mil03c849.html?tmpl=component\&print=1\&page=\&lang=en

[https://perma.cc/B2C2-JLHJ] (issued by the Military Commander of the West Bank)).

236 BENVENISTI, supra note 26, at 234-36; GROSS, supra note 140, at 174 (noting that orders issued by the Military Commander "confer special status on Jewish settlements in the [occupied Palestinian territory] by applying to these territorial units certain aspects of Israeli law in various spheres, such as education, granting them the privileges enjoyed by localities within Israel.").

237 BENVENISTI, supra note 26, at 236.

238 See HCJ 336/99 Delta Inv. \& Com. (Karnei Shomron) Ltd. v. Court of Domestic Affs. in Ariel, 55(3) PD 246, 260 (2001) (cited in Ass'N FOR CIV. RTS. IN IsR., supra note 227, at 20) (The Supreme Court of Israel noted that one of the purposes of establishing the Courts of Domestic Affairs was to achieve "maximal equalization between proceedings in the area court [courts in the West Bank serving the settlements] and proceedings in courts in Israel.").

239 BENVENISTI, supra note 26 , at 237. 
Courts of Domestic Affairs granted them jurisdiction to adjudicate a broad range of civil and criminal matters, and provided for the application of Israeli laws to the settlements in the fields of welfare law, personal status law, education law, health law, labor law, agriculture law, condominium law, environmental law, consumer protection and commerce law, communications law, and religion laws. ${ }^{240}$

Eyal Benvenisti observed that:

The enactments of the military authorities created a special legal system in the settlements, a system that adopted Israeli law, administration, and jurisdiction while at the same time excluding them from otherwise applicable local laws .... [T] he by-laws created in the settlements a legal environment similar to that found within Israel. ${ }^{241}$

Commentators have observed that the partial application of Israeli law to the West Bank has blurred the boundaries between Israel and the West Bank, transforming the status of the latter from "escrow" held in trust by the occupier to legal "mongrel," as the occupied territories "have gradually been incorporated in practice into the realm of Israel's rule." 242

240 Id. at 236; Ass'N FOR CIV. RTS. IN IsR., supra note 227, at 20-21.

241 BENVENISTI, supra note 26, at 235-36 (observing further that " $\mathrm{t}$ ] he municipal regime of the settlements enacted by the by-laws was fashioned according to the Israeli municipal system. Many provisions in the by-laws explicitly incorporated Israeli primary and secondary legislation, including provisions relating to planning and building and to licensing of businesses.").

242 Amnon Rubinstein, The Changing Status of the "Territories" (West Bank and Gaza): From Escrow to Legal Mongrel, 8 TEL AvIV U.STUD. L. 59, 67, 79 (1988); see also Ben-Naftali, Gross \& Michaeli, supra note 7, at 586. Tamar Hostovsky Brandes argues that the jurisprudence of the Israeli Supreme Court has contributed to the "creeping annexation" of the West Bank. Hostovsky Brandes, supra note 232, at 2. Hostovsky Brandes commented on the judicial review exercised by the Supreme Court over the actions of Israeli authorities with regard to the West Bank, observing that "while the international law of occupation still operates, officially, as the governing normative framework in the Occupied Territories, . . . the Court has increased its reliance on Israeli administrative law, and, in recent years, also on Israeli constitutional law. As a result, the distinction between the Occupied Territories and Israel is blurred." Id. 


\section{b. The Parameters of de facto Annexation}

Discussion by courts and commentators of the existence of annexation beyond situations of formal annexation has revolved around the notion of de facto annexation. ${ }^{243}$ This discussion addressed de facto annexation as a concept that denotes, in the same way that formal annexation does, a violation by the occupier of the prohibition against the use of force or of the right of the people under occupation to self-determination. ${ }^{244}$ Attempts to define de facto annexation have also concerned the significance of this form of annexation as a parameter of the illegality of occupation. ${ }^{245}$ This discussion reveals three possible tests for the existence of de facto annexation.

\section{i. $\quad$ The Purpose-Based Test for Annexation}

The purpose-based test for de facto annexation assumes that the conduct of an occupier that falls short of a formal act of annexation, but nevertheless attests to the occupier's "intention to hold the territory permanently under its dominion," 246 must be considered as

243 Infra notes 244-245.

244 BENVENISTI, supra note 26, at 245, 349 (noting that de facto annexation amounts to aggression); Ben-Naftali, Gross \& Michaeli, supra note 7, at 553-56, 592, 597-605 (inferring from the right of peoples to self-determination and from the principle regarding the inalienability of sovereignty through the use of force a "reasonable time" limit on the duration of occupation, and arguing that de facto annexation marks a violation of this norm); Kleinfeld, supra note 18, at 2472-76, 2494-98 (addressing possible tests for the existence of de facto annexation, and noting that such annexation implicates the norm concerning the inadmissibility of the acquisition of territory by war); Dajani, supra note 18, at 51 (asking whether conduct that amounts to de facto annexation "rise[s] beyond a violation of the jus in bello to contravene the jus ad bellum"); Legal Consequences of the Construction of a Wall in the Occupied Palestinian Territory, Advisory Opinion, 2004 I.C.J. 136, I 184 (July 9) (noting that actions by Israel that may result in the de facto annexation of parts of the West Bank violate the right of the Palestinian people to self-determination).

245 Ben-Naftali, Gross \& Michaeli, supra note 7, at 601-05.

246 Dajani, supra note 18, at 52 (noting that traditional international law considered annexation to have occurred whenever a conquering state that had gained "effective possession" of the territory in question clearly manifested its "intention to hold the territory permanently under its dominion"); see also COLEMAN 
a form of annexation. This approach takes into account a broad range of conduct on the part of the occupier that reveals annexationist intentions. Such conduct may include the refusal by the occupier to engage in good faith negotiations aimed at ending the occupation, statements by officials of the occupying state that do not amount to formal annexation but indicate that the occupier considers the occupied territory its own, legal measures that partially apply the laws and administration of the occupying state to the occupied territory, and the establishment by the occupier of facts on the ground that contribute to the integration of the occupied territory into the territory of the occupier. It has thus been argued that the vast settlement enterprise conducted by Israel in the West Bank, the infrastructure facilitating the integration of the settlements into Israel, ${ }^{247}$ statements made by Israeli officials regarding the political purpose of the settlements and of the Barrier, and the partial application by Israel of its laws to the occupied territories reveal a political purpose of perpetuating Israel's possession of parts of the West Bank.248 It has been argued that the intention revealed by the conduct of Israel meets the test for de facto annexation. ${ }^{249}$

Phillipson, Termination of War And Treaties of Peace 9 (1916) (cited in Dajani, supra note 18 , at 52 ).

247 See supra notes 213-222 and accompanying text (discussing the road system connecting the settlements to Israel and the Barrier separating most settlements from other parts of the West Bank).

248 See Martel, supra note 212, at 335; Ben-Naftali, Gross \& Michaeli, supra note 7, at 601 (inferring from Israel's actions in the West Bank "an intention to retain its presence there indefinitely"); John Dugard (Special Rapporteur of the Commission on Human Rights), Question of the Violation of Human Rights in the Occupied Arab Territories, Including Palestine, - 41, U.N. Doc. E/CN.4/2004/6 (Sept. 8, 2003) [hereinafter Report of the Special Rapporteur] ("[T]he construction of the Wall within the West Bank and the continued expansion of settlements, which, on the face of it, have more to do with territorial expansion, de facto annexation or conquest, raise serious doubts about the good faith of Israel's justifications in the name of security."); David Kretzmer, The Advisory Opinion: The Light Treatment of International Humanitarian Law, 99 AM. J. INT'L. L. 88, 92 (2005) ("The debate in Israel clearly demonstrates that the government did indeed have political intentions in setting the barrier's route."); Dajani, supra note 18, at 54 (arguing that Israel's actions in the West Bank are probative of annexationist intent).

249 Dajani, supra note 18, at 55 (submitting that, in view of annexationist intentions demonstrated by Israel through its actions in the West Bank and the position taken by Israeli negotiators, "the international community need not wait for a formal act of annexation to consider that it has occurred"); Report of the Special Rapporteur, supra note 248, at 16 ("[T] he fact must be faced that what we 
Examining the lawfulness under international law of the construction of the Barrier, the Supreme Court of Israel rejected the view that this measure revealed an annexationist intention on the part of Israel. 250 The Court acknowledged that "the Military Commander is not authorized to order the construction of the separation fence if his reasons are political. The purpose of the separation fence cannot be the 'annexation' of territories [of the West Bank] to the State of Israel. The purpose of the separation fence cannot be to draw a political border." 251 The Court proceeded to conclude, however, that the construction of the Barrier was not motivated by a political purpose of shaping the borders of Israel, but rather by the security interest in preventing the infiltration of terrorists into Israel and into the Israeli settlements in the West Bank. ${ }^{252}$ The Court did not consider whether the establishment by Israel of settlements in the West Bank and the partial application of Israeli law to the West Bank reveal an annexationist intention. Rather, the Court addressed the construction of the Barrier in isolation from other measures taken by Israel that facilitate the integration of parts of the West Bank into Israel, considering the settlements only as the premise of the security argument for the incursion of the Barrier into the West Bank. ${ }^{253}$

A review of the legal literature reveals nuanced approaches to the application of the purpose-based test for de facto annexation. According to one approach, the required intention on the part of the occupier must be "to take territory in perpetuity ... to take sovereignty." 254 I term this approach the "narrow purpose-based test for annexation." The second approach extends the definition of annexation to any significant prolongation by the occupier of the occupation that is contrary to international law. Such an approach

\footnotetext{
are presently witnessing in the West Bank is a visible and clear act of territorial annexation under the guise of security."); Ben-Naftali, Gross \& Michaeli, supra note 7, at 601-05 (concluding that the actions of Israel in the West Bank amount to de facto annexation because they reveal an intention on the part of Israel to retain its presence in this territory indefinitely). (2004) (Isr.).

250 HCJ 2056/04 Beit Sourik Village Council v. Gov't of Isr., 43 ILM 1099, 1108

251 Id.

252 Id. at 1109.

253 Id.

254 Kleinfeld, supra note 18, at 2472.
} 
measures the existence of de facto annexation based on the range of interests that an occupier may legitimately promote by maintaining the occupation and negotiating its termination, which many commentators view to be limited to reasonable security considerations. ${ }^{255}$ An occupied territory is considered to have been annexed if the occupier prolongs the occupation to advance interests that exceed this range of legitimate interests, even if an intention to take the territory in perpetuity cannot be established. I term this approach the "broad purpose-based test for annexation." Applying this approach, Eyal Benvenisti observed that the occupier has a duty under international law to negotiate in good faith a peaceful solution ending the occupation, and that "the failure to do so should be considered outright annexation," 256 in violation of international law. 257 Benvenisti asserted that the conduct of good faith negotiations requires the occupier to limit the conditions it presents for ending the occupation to "reasonable security interests," 258 and implied that such interests are restricted to those security objectives that a state may promote in a war of self-defense. 259

Under the broad purpose-based test for annexation, Israel could be viewed to have annexed a given area of the West Bank if it uses the occupation of that area as a bargaining chip to extract Palestinian territorial concessions with regard to other parts of the West Bank. Annexation would also result under this approach if Israel uses the occupation to extract a Palestinian concession with regard to the

255 See BENVENISTI, supra note 26, at 245-46 (“[N]o . . claim of illegality would be proper as long as the occupant's conditions for peaceful settlement of the conflict are motivated by reasonable security interests."); CASSESE, supra note 26, at 55 (arguing that an occupier may not maintain the occupation unless "it is justified by Article 51 of the UN Charter [i.e., the self-defense exception to the prohibition on the use of force] and, therefore, being restricted to the need to repel an act of aggression, is limited in duration"); see also Stephen M. Schwebel, Editorial Comment, What Weight to Conquest?, 64 AM. J. INT'L L. 344, 345-46 (1970) (“A state acting in lawful exercise of its right of self-defense may seize and occupy foreign territory as long as such seizure and occupation are necessary to its self-defense. ... As a condition of its withdrawal from such territory, that state may require the institution of security measures reasonably designed to ensure that that territory shall not again be used to mount a threat or use of force against it of such a nature as to justify exercise of self-defense.").

\footnotetext{
256 BENVENISTI, supra note 26, at 245.

257 Id. at $245,349$.

258 Id. at 246

259 Id. at 17.
} 
claim of the Palestinians to a right of return of Palestinian refugees to the territory of Israel proper; to advance any other political interest transcending security considerations; or to promote security interests that exceed the limits of the right to self-defense.

\section{ii. The Effects-Based Test for Annexation}

The second test for de facto annexation is effects-based. This test was adopted by the ICJ in the Wall Advisory Opinion. The Court addressed the question of de facto annexation in considering whether the construction of the Barrier in the West Bank violated the right of the Palestinian people to self-determination. ${ }^{260}$ The government of Israel assured the Court that the Barrier was not intended as an instrument of annexation, but rather "solely as a temporary, nonviolent defensive measure to guard against suicide and other attacks against Israel and Israelis." 261 The ICJ noted the assurance provided by Israel regarding the purpose of the Barrier, leaving it unchallenged without any further evaluation of its credibility. ${ }^{262}$ The ICJ also refrained from examining whether the settlement enterprise and the legal regime applied by Israel to the settlements and to the settlers reveal an annexationist intention on the part of Israel, which meets the purpose-based test for de facto annexation. Noting, however, that the area between the Barrier and the Green Line would include most Israeli settlements illegally established in the West Bank, and that the construction of the Barrier would likely

260 Legal Consequences of the Construction of a Wall in the Occupied Palestinian Territory, Advisory Opinion, 2004 I.C.J. 136, If 122 (July 9).

261 Written Statement of the Government of Israel on Jurisdiction and Propriety 1 1.8, Legal Consequences of the Construction of a Wall in the Occupied Palestinian Territory, Advisory Opinion, 2004 I.C.J. 136, ๆ 122 (July 9), https://www.icj-cij.org/public/files/case-related/131/1579.pdf [https://perma.cc/MP6J-24L8].

262 See Legal Consequences of the Construction of a Wall in the Occupied Palestinian Territory, Advisory Opinion, 2004 I.C.J. 136, 121 (July 9); see also Kretzmer, supra note 248, at 92 (noting that the ICJ refrained from contesting Israel's assurance that the Barrier is not an instrument of annexation "probably because it did not have the evidentiary basis to do so"). 
contribute to the departure of Palestinians from this area, changing its demographic composition, 263 the Court proceeded to state:

[The Court] cannot remain indifferent to certain fears expressed to it that the route of the wall will prejudge the future frontier between Israel and Palestine, and the fear that Israel may integrate the settlements and their means of access. The Court considers that the construction of the wall and its associated régime create a "fait accompli" on the ground that could well become permanent, in which case, and notwithstanding the formal characterization of the wall by Israel, it would be tantamount to de facto annexation. 264

Joshua Kleinfeld observed that:

This is essentially an effects-based test for annexation; the suggestion is that the Barrier might change facts on the ground (demographics, for example, as Israelis move into and Palestinians move out of the West Bank land on the Israeli side of the Barrier) in such a way as to make a restoration of the Green Line untenable in the future. 265

The effects-based test hinges upon the identification of the point of no return, which marks a factual integration of the occupied territory into the occupying state, which is so entrenched that it cannot be reversed.

Applying the effects-based test, the ICJ appears to have been unconvinced that the integration of parts of the West Bank into Israel, resulting from Israeli policies, has reached the point of no return. The Court stopped short of determining that the construction of the Barrier, considered together with the settlement enterprise, currently amount to de facto annexation. Rather, the Court observed that the Barrier has the potential of becoming a permanent, irreversible reality, "in which case ... it would be tantamount to de facto annexation." 266 The Court took the view that

263 See Legal Consequences of the Construction of a Wall in the Occupied Palestinian Territory, Advisory Opinion, 2004 I.C.J. 136, 1122 (July 9).

$264 \quad$ Id. $ๆ 121$.

265 Kleinfeld, supra note 18, at 2474-75.

266 Legal Consequences of the Construction of a Wall in the Occupied Palestinian Territory, Advisory Opinion, 2004 I.C.J. 136, ๆ 121 (July 9). 
the possibility that the Barrier becomes a permanent reality in the future suffices to conclude that its construction violates the right of the Palestinian people to self-determination. ${ }^{267}$

\section{iii. The Display of Sovereignty Test for Annexation}

ICJ Judge Koroma, concurring with the Wall Advisory Opinion of the Court, took the view that "the construction of the wall has involved the annexation of parts of the occupied territory by Israel, the occupying Power, contrary to the fundamental international law principle of the non-acquisition of territory by force." 268 Judge Koroma reasoned that by building the wall inside the occupied Palestinian territories, Israel has "embark[ed] there on activities of a sovereign nature which will change their status as occupied territory." 269 This approach, equating annexation with "activities of a sovereign nature" on the part of the occupier, suggests a test for the existence of annexation that brings together formal and de facto annexation. This test for annexation, which I term the display of sovereignty test, requires the occupier's continuous exercise in the occupied territory of governmental functions that are typically reserved to a sovereign.

The display of sovereignty test is naturally satisfied by formal annexation, namely, the full extension by the occupier of its legal and administrative systems to the occupied territory. 270 Yet, activities of a sovereign nature, which satisfy the display of sovereignty test for annexation, may also take the form of the settlement by the occupier of its own population in the occupied territory, substantial infrastructure projects aimed at supporting

267 Id. ๆ 122.

268 Legal Consequences of the Construction of a Wall in the Occupied Palestinian Territory, Advisory Opinion, Separate Opinion of Judge Koroma, 2004 I.C.J. 136, ๆ 2 (July 9).

269 Id.

270 See supra notes 195-200 and accompanying text. 
such settlement activity, and a partial extension of the occupier's legal system to the occupied territory. ${ }^{271}$

Advancement by the occupier of the purpose of holding the territory in perpetuity typically entails conduct that amounts to the display of sovereignty. 272 The distinction between the narrow purpose-based test for annexation, which requires an intention to hold the territory in perpetuity and the display of sovereignty test is therefore of little practical significance.

By contrast, the distinction between the display of sovereignty test and the broad purpose-based test for annexation seems significant. An occupier could conceivably prolong the occupation significantly by using it as a bargaining chip to advance illegitimate interests, conduct that amounts to de facto annexation under the broad purpose-based test, while otherwise complying with a range of international humanitarian law provisions that prohibit an occupier from actions amounting to the display of sovereignty.273 The display of sovereignty test for de facto annexation is also distinct from the effects-based test, as the display of sovereignty by the occupier does not necessarily result in permanent, irreversible integration of the occupied territory into the occupying state.

271 GROSs, supra note 140, at 172 ("Israel's establishment of settlements in the [occupied Palestinian territory], together with the application of Israeli law to the settlements and their residents, are more an exercise of sovereignty than of occupation."); id. at 176 ("Israel acts in the [occupied Palestinian territory] as a sovereign insofar as it settles its citizens there and extends to them its laws on a personal and on a mixed personal/territorial basis.").

272 Dajani, supra note 18, at 53 (applying the purpose-based test for annexation, Dajani notes that a state's "intention to hold a territory 'under its dominion,' . . . may be signaled by a state's exercise, for a prolonged time, of the kinds of governmental functions typically reserved to a sovereign.").

273 Examples of such humanitarian law prohibitions include Article 49(6) of the Fourth Geneva Convention, which prohibits the occupying state from settling its own population within the occupied territory, and Article 64 of the Convention, which limits the liberty of the occupier to legislate for the occupied territory. See Fourth Geneva Convention, supra note 209, arts. 49, 64. 


\section{c. The Proposed Test for Annexation for the Purpose of the Right to} Citizenship

This Article proposes the application of the display of sovereignty test for annexation in determining whether West Bank Palestinians have a right to Israeli citizenship. According to this view, the prolongation of the occupation, even if linked to annexationist intentions of the occupier, does not in itself amount to annexation. The parameters of annexation consist in, and are limited to, actions by the occupier, both in the form of legal measures and in the establishment of facts on the ground, which bear the distinguishing mark of sovereignty.

Part III has shown that applying the norms of IHRL on citizenship to the relationship between the residents of an illegally annexed territory and the annexing state requires an exception to the principle that illegal annexation has no legal effect. The ILC concluded, relying on IHRL, that situations of state succession, including the lawful annexation of territory by the successor state, give rise to a right of the residents of the territory in question to receive the citizenship of the successor state, but excluded situations of illegal annexation from the scope of its analysis.274 According to the argument for extending the norms of IHRL on citizenship also to the illegal annexation of territory by an occupier, the reality facing the residents of an annexed territory, and therefore their interests in obtaining the citizenship of the annexing state, are similar in the case of both legal and illegal annexation. This argument informs the appropriate test for the existence of illegal annexation.

For the purpose of the right to citizenship, the concept of illegal annexation denotes a factual reality that resembles the one that typically emanates from the lawful acquisition of a territory by a state. Determining the existence of illegal annexation by the occupier reflects the recognition that the occupied territory has become, in reality, a part of the occupying state, and that the residents of that territory are therefore entitled to receive the citizenship of the occupying state in the same way that residents of a territory that has been lawfully acquired by a state are entitled to its citizenship. Pronouncing the existence of illegal annexation

274 See supra notes 85-91, 168-171 and accompanying text. 
conveys that the former are on a par with the latter when it comes to the right to citizenship because of the similarity between the factual realities. This function of the concept of illegal annexation ties the existence of annexation to the occupier's treatment of the occupied territory as its own, and therefore points to the display of sovereignty test for annexation.

The display of sovereignty test for annexation is a factual test, but its application may be informed by normative considerations. A strict application of the display of sovereignty test would preclude extending the scope of annexation to portions of an occupied territory that are not the object of the occupier's annexationist policies. There is, however, a strong normative argument against allowing an occupier to pick and choose small, densely populated areas within the occupied territory that the occupier would exclude from the realm of annexation and thereby from the sway of the right to citizenship. This argument concerns both the principle of legality in international law and the right to self-determination.

Annexation of occupied territory violates jus cogens and is considered under international law to be null and void.275 Attaching to such annexation legal consequences that extend as far as citizenship, which is the distinguishing mark of the relationship between individuals and their state, erodes the political force of this legal principle and implicitly indicates a degree of recognition by international law of the validity of the illegal annexation. This exacts a toll on the principle of legality in international law. A theory that derives a right of West Bank Palestinians to Israeli citizenship from the annexation of occupied territories by Israel accepts such costs. It seems, however, that the principle of legality would be further harmed if the occupier were allowed to tailor an "illegal annexation bargain" that is most favorable to it with respect to the legal and political consequences of annexation. This would be the case if the occupier were allowed to draw, applying a "maximum land, minimum population" formula, the boundaries of the illegally annexed territory whose residents are entitled to the occupier's citizenship, and with regard to which a sovereignty claim by the occupier would gain political strength.

Granting legal effect, insofar as citizenship rights are concerned, to efforts on the part of Israel to design the annexation so that it

275 See sources cited supra notes 140-145. 
encompasses as much territory and as little of the population as possible would greatly facilitate and benefit such efforts. The application by Israel of such annexation policy may diminish the capacity of the Palestinian people to exercise its right to selfdetermination in the form of statehood to the point where Palestinians are completely divested of that right. An international stance that benefits such policy, leaving most Palestinians without an alternative option of realizing the right to self-determination through the exercise of Israeli citizenship rights, would be detrimental to the right of the Palestinian people to selfdetermination.

When the geographic spread of displays of sovereignty by the occupier resembles a thick web, viewing the entire occupied territory covered by that web, including the "holes" in which the occupier does not act as a sovereign, as subject to annexation does not seem a significant stretch of the display of sovereignty test for annexation. Similarly, the greater the geographic proximity between (a) areas within the occupied territory that are subject to displays of sovereignty by the occupier and (b) other occupied areas in which the occupier did not act as a sovereign, the more plausible it is to consider the latter to have been annexed under the display of sovereignty test.

As noted above, settlement activity by the occupier is a form of display of sovereignty that contributes significantly to the existence of annexation. Currently, over two hundred Israeli settlements and settlement outposts are spread across the entire West Bank. ${ }^{276}$ Considering the small size of the West Bank (approximately 2,180 square miles), 277 it is clear that the settlements, the infrastructure supporting them, and the legal regime applied by Israel to the settlements form a thick web of displays of sovereignty on the part of Israel throughout the West Bank. Therefore, a reasonable application of the display of sovereignty test, which is based on the current map of settlements and is informed by the normative interest in preventing the tailoring by the occupier of a "maximum land, minimum population" annexation map, would result in the

\footnotetext{
276 See supra notes 207-208 and accompanying text.

277 West Bank, ENCYCLOPEDIA BRITANNICA, https://www.britannica.com/place/West-Bank [https://perma.cc/P9W3NBKN] (last visited Oct. 30, 2020).
} 
entire West Bank being considered to have been annexed. This result would allow all West Bank Palestinians to claim a right to Israeli citizenship based on the emerging right to citizenship in customary IHRL.

Given the small size of the West Bank, a distribution of settlements that avoids the annexation of the entire West Bank under the display of sovereignty test would have to be confined to the margins of this territory, requiring the removal of a large number of settlements. Settlements located at the margins of the West Bank would not color the entire West Bank as annexed territory, but would bring into the realm of annexation any Palestinian city, town, or village in their vicinity that is located between two settlements or between an Israeli settlement and the territory of Israel proper, defined by the Green Line.

The above discussion suggests that, in view of the current map of settlements, the formal annexation planned by Israel would not have a transformative effect on the status of the West Bank. Even in the absence of formal annexation, the settlement enterprise satisfies the display of sovereignty test for annexation with regard to the entire West Bank.

The application of the proposed test for annexation must take into account the devastating effect that granting Israeli citizenship to all or most West Bank Palestinians would have on the character of Israel as a Jewish state. The next section addresses the tension between the interest in Israel maintaining such character and the emerging right of West Bank Palestinians to Israeli citizenship and discusses the legal consequences of such tension for the application of the proposed test for annexation.

\section{d. The Annexation of West Bank Territories and the Character of Israel as a Jewish State}

The existence of the State of Israel as a Jewish state has been justified as the expression of the right of the Jewish people to selfdetermination. 278 The view that a Jewish state is a proper manifestation of the right of the Jewish people to self-determination

278 Frances Raday, Self-Determination and Minority Rights, 26 FORDHAM INT'L L.J. 453, 470 (2003). 
relies primarily on an argument that is analogous with affirmative action theory. ${ }^{279}$ It has been noted that "affirmative action policies are routinely justified on the basis of compensation for past discrimination," 280 and that this justification "work[s] well in defense of a Jewish state. In terms of historical discrimination, Justice Frankfurter's observation that the Jews represent 'the most vilified and persecuted minority in history' can hardly be denied." 281 Elaborating on the strength of the right of the Jewish people to selfdetermination in the form of a Jewish state, Frances Raday observed:

The Jewish claim to self-determination is based on the desperate need to correct historic wrongs on a global scale, resulting from persecution and discrimination by a majority of host States over nearly two thousand years of history and culminating in the Holocaust in Europe in the twentieth century. It is, arguably, the only case of a claim to selfdetermination in rem, as it might be termed, against the entire world. 282

The character of Israel as a Jewish state hinges on the retention of a solid Jewish majority among citizens of the country, which would not be possible if the bulk of the Palestinian population of the West Bank were granted Israeli citizenship. ${ }^{283}$ This does not justify the type of ethnic oppression manifested in the denial of citizenship to non-Jewish residents of territory annexed by Israel, either formally or de facto. Reliance on the right of the Jewish people to self-determination cannot pave the way to a legal regime whose hallmark is the rule of one ethnic group over another through the discriminatory denial of citizenship rights, which would bear resemblance to an apartheid regime.

279 See Zasloff, supra note 80, at 208.

280 Id.

281 Id. at 209.

282 Raday, supra note 278 , at 462.

283 Id. at 470 ("The Israeli government is not and cannot become sovereign over the entire Palestinian population of the West Bank and Gaza without forfeiting the expression of its own self-determination. The basis for Israeli Statehood has been and continues to be the right of the Jewish people to self-determination. For this to be feasible, the State of Israel must have a majority of Jews in the population and hence, the government.") 
I argue, however, that the legal significance of the right of the Jewish people to self-determination justifies allowing Israel a reasonable time period to secure its Jewish character in a manner that is consistent with the emerging right to citizenship and its application to cases of annexation. There is strong precedent in constitutional and administrative law of various jurisdictions for allowing the state a reasonable adjustment period where an immediate application of the law stated by the courts would be detrimental to a legitimate interest of the state or to individual interests. Domestic courts enunciating the unconstitutionality of legislation often postpone its nullification for an adjustment period during which the legislator can determine how to remedy the constitutional flaw. ${ }^{284}$ Such postponement was deemed necessary to prevent a "legislative void" that would compromise an essential public interest. ${ }^{285}$ For similar reasons, domestic courts pronouncing the unlawfulness of administrative rules have increasingly turned to the practice of remanding such rules without vacating them, which allows the administrative agency to continue to implement the rule as it works to amend the flaws underlying its unlawfulness. 286

International law requires a state in violation of an international law obligation to cease such violation immediately and unconditionally. ${ }^{287}$ In view of the innovative nature of the proposed legal construction that would entitle the Palestinians to Israeli citizenship based on unlawful, de facto annexation, it is possible,

284 See Schachter v. Can. [1992] 2 S.C.R. 679 (Can.); HCJ 1715/97 Chamber of Inv. Managers in Isr. v. Minister of Fin., 51(4) PD 367, 417 (1997); see also Saliternik, supra note 161 , at 1281 .

285 Schachter, 2 S.C.R. at 715 ("A Court may strike down legislation or a legislative provision but suspend the effect of that declaration until Parliament... has had an opportunity to fill the void. This approach is clearly appropriate where striking down of a provision poses a potential danger to the public ... or otherwise threatens the rule of law ... ."); Chamber of Inv. Managers in Isr., supra note 284, 51(4) PD at 417.

286 Saliternik, supra note 161, at 1270-1272 (reviewing such decisions by U.S. courts).

287 Olivier Corten, The Obligation of Cessation, in THE LAW OF INT'L RESPONSIBILITY 545, 548 (James Crawford, Alain Pellet \& Simon Olleson eds., 2010) ("In law, a State must and can always put an end to a continuing breach [of international law]."); Draft Articles on Responsibility of States, supra note 146, at 88, art. 30 (stipulating that a state "responsible for internationally wrongful conduct is under an obligation" to cease such conduct, if it is continuing, without recognizing the possibility of a permissible delay in the performance of this obligation). 
however, to construe the obligation of Israel to grant such citizenship as one that will have consolidated only after the passage of a reasonable adjustment period, which allows Israel to narrow the scope of annexation through the removal of settlements.

It would fall to the international community of states to determine, in view of the future conduct of Israel, what amounts to a reasonable adjustment period. Matthew Waxman has observed that "[f]or the most part . . . application and enforcement of international law are decentralized, occur outside formal international institutions, and remain largely the province of states." 288 Because states are the primary compliance agents with regard to international law, the content of a state's obligations under international law depends on the views of other states. As noted by Andrew Guzman and Timothy Meyer, "obligations are, to a large extent, in the eye of the beholder. In a legal system in which enforcement relies on self-help by the law's subjects, those subjects' perceptions as to what an obligation requires effectively define the obligation." 289 Presumably, an ICJ Advisory Opinion construing what amounts to a "reasonable adjustment period" would carry considerable weight in forging the views of the international community of states on this matter.

\section{CONCLUSION}

The annexationist policies of Israel in the occupied West Bank give rise to flagrant discrimination between the population of Israel and the Palestinian population of the West Bank, which has the distinguishing marks of a colonial regime. Such discrimination is the result of the denial of Israeli citizenship to West Bank Palestinians, and of Israel treating the occupied territory as its own, without assuming in relation to the local population the duties that a sovereign has toward its nationals.

This Article has explored a path in international law for recognizing the right of the Palestinian population of the West Bank

288 Matthew C. Waxman, Regulating Resort to Force: Form and Substance of the UN Charter Regime, 24 EURO. J. INT'L L. 151, 153 (2013).

289 Andrew T. Guzman \& Timothy L. Meyer, International Soft Law, 2 J. LEGAL ANALYSIS 171, 174 (2010). 
to Israeli citizenship. The Article showed that, to the extent that Israel is deemed to have annexed a given area of the West Bank, it is required under treaty law to grant its citizenship to many of the Palestinian residents of such territory. Moreover, emerging norms of customary international law would require Israel to grant its citizenship to all Palestinians residing in an area of the West Bank annexed by Israel.

The Article argued further that the enterprise of Israeli settlements across the West Bank amounts to annexation, which currently extends to the entire territory of the West Bank. Hence, unless Israel narrows the scope of annexation, within a reasonable time period, by removing many of the settlements, Israel's obligations under existing and emerging norms of IHRL concerning the right to citizenship would apply to the relationship between Israel and all West Bank Palestinians. 